$$
\begin{gathered}
0512.6 \\
I-17655
\end{gathered}
$$

LA-10226-M

Manual

(ISPO-215)

PROCRAM FOR

TECHINICAL ASSISTANCE

USA TO IAEA SAFEgUARDS

IAEA Deportment of Enovgr

NOTIEE

PORTIONS OF THIS REPOST ARE HLEgIBLE.

It has been reproduced from the best available copy to permit the broatlest posssble availability.

\title{
Universal Fast Breeder Reactor Subassembly Counter Manual
}

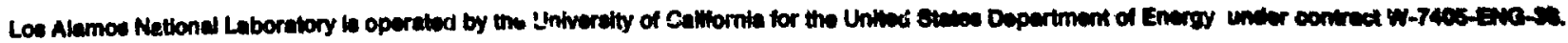




\title{
Universal Fast Breeder Reactor Subassembly Counter Manual
}

\author{
H. O. Menlove \\ G. W. Eccleston \\ J. E. Swansen \\ P. Goris* \\ R. Abedin-Zadeh"* \\ A. Ramalho**
}

\section{DISCLAIMER}

This report was prepared as an account of work sponsored by an agency of the United States Government. Neither the United States Government nor any agency thereof, nor any of their employees, makes any warranty, express or implied, or assumes any legal liability or responsibility for the accuracy, completeness, or usefulness of any information, apparatus, product, or process disclosed, or represents that its use would not infringe privately owned rights. Reference herein to any specific commercial product, process, or service by trade name, trademark, manufacturer, or otherwise does not necessarily constitute or imply its endorsement, recommendation, or favoring by the United States Government or any agency thereof. The views and opinions of authors expressed herein do not necessarily state or reflect those of the United States Government or any agency thereof.

"Westinghouse Hantord Company, Richland, WA 98352.

- International Atomic Energy Agency, Vienna, AUSTAIA. 
UNIVERSAL FAST BREEDER REACTOR SUBASSEMBLY COUNTER MANUAL

by

H. O. Henlove, G. W. Eccleston, J. E. Swansen, P. Goris, R. Abedin-Zadeh, and A. Ramalho

\begin{abstract}
A neutron coincidence counter has been designed for the measurement of fast breeder reactor fuel assembijes. This assay system can accommodate the full range of geometries and masses found in fast breeder subassemblies unde." IAEA sareguards. The system's high-performance capability accommodates high plutonium loadings of up to $16 \mathrm{~kg}$. This manual describes the system and its operation and gives performance and calibration parameters for typical applications.
\end{abstract}




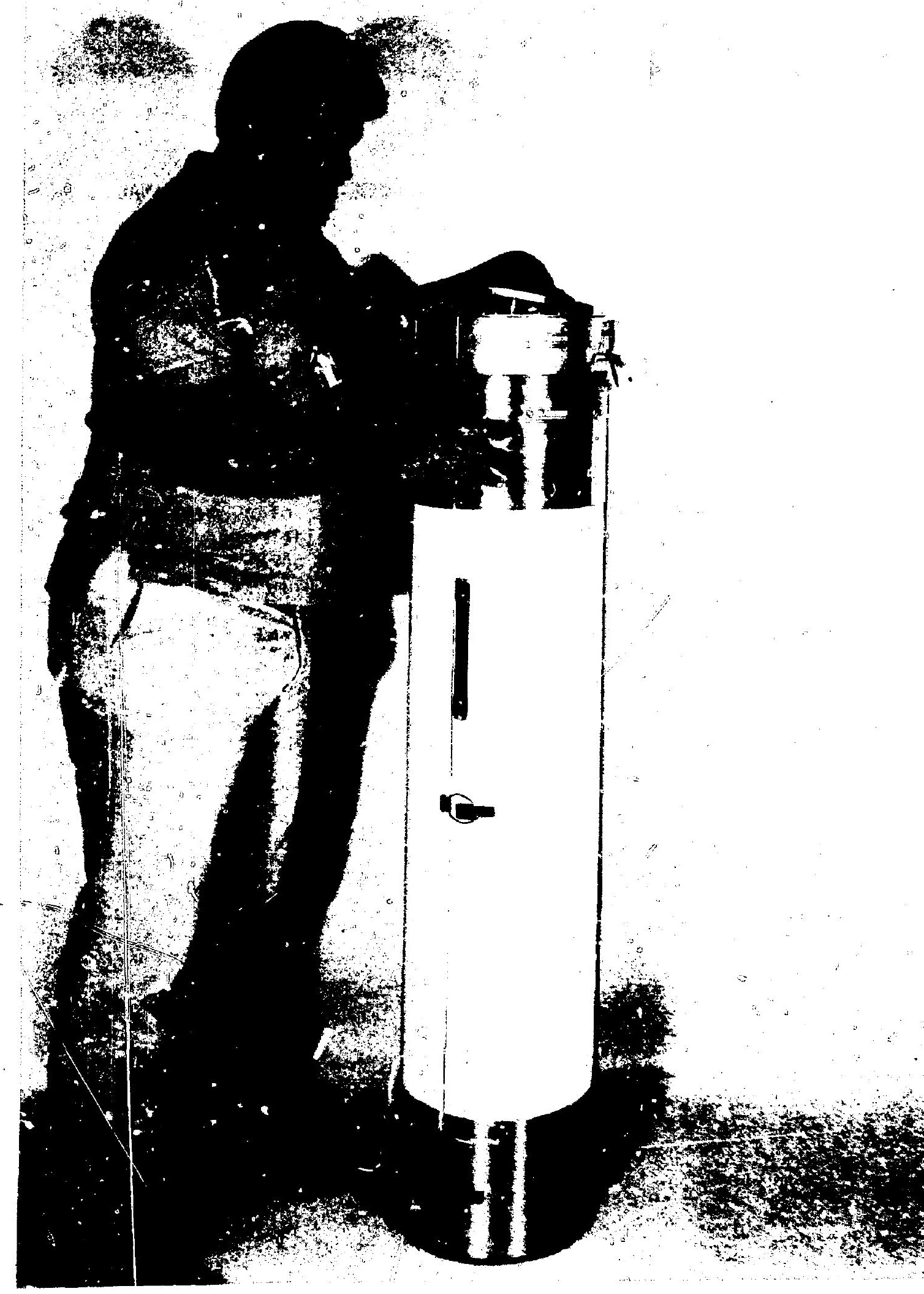


The International Atomic Energy Agency (IAEA) inspectors need the capability to conduct independent on-site verification for the plutonium in fast breeder reactor (FBR) fuel. We have designed a neutron coincidence counter for the quantitative verification of the amount of plutonium in ful 1 subassemblies as well as in individual pins or groups of pirs. This assay system is called the Universal Fast Breeder Reactor Subassembly Counter (UFBC). The system consists of a detector head with stand, a shift register electronics unit, and an HP-97 programmable calculator or HP-85 mini-computer.

The UFBC system can be used for the measurement of FBR subassemblies for plutonium loadings up to $16 \mathrm{~kg}\left(24 \%{ }^{240} \mathrm{Pu}\right)$. The maximum sample diameter is $16.5 \mathrm{~cm}$, and the uniform counting (flat response) region in the detector head is $105 \mathrm{~cm}$. This loading and size capability covers all of the FBRs under IAEA safeguards verification.

This system resembles the high-level neutron coincidence counter $^{1}$ (HLNCC) in that it uses similar digital electronics $^{2}$ and detects the coincidence neutrons from the spontaneous fission of the ${ }^{240}$ Pu-effective ${ }^{1}$ mass. However, it is designed to operate for much taller samples $(21.0 \mathrm{~m})$ than the HLNCC and at much higher counting rates.

This manuaz describes the components, performance characteristics, and operating and calibration procedures for the UFBC counter. 
DETECTOR BODY

Figure 1 is a photograph of the UFBC system detector head. The detector head is $141 \mathrm{~cm}$ high and $30.5 \mathrm{~cm}$ in diameter. It weighs $55 \mathrm{~kg}$. Figure 2 shows the open door in the detector for side entry of fuel subassemblies. The sample cavity accommodates samples that fit in the 17-cm-diam through-hole.

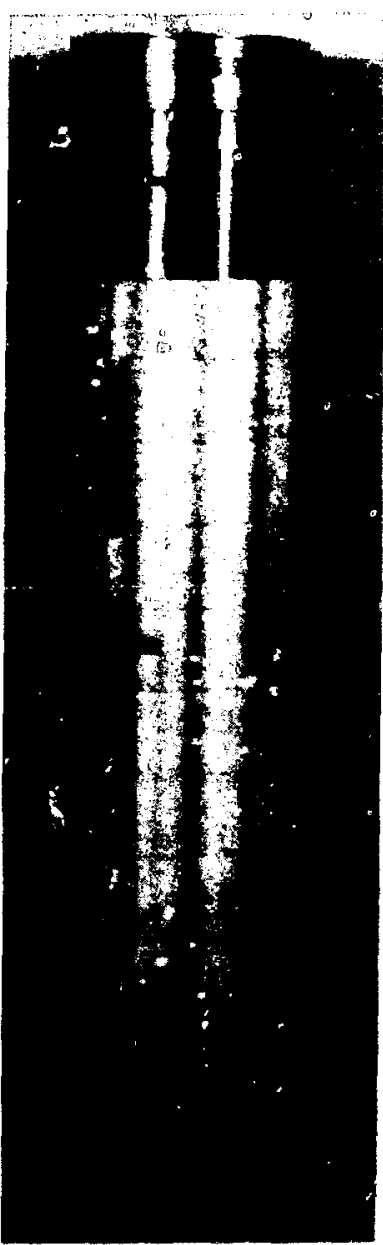

Fig. 1. UFBC counter detector head.

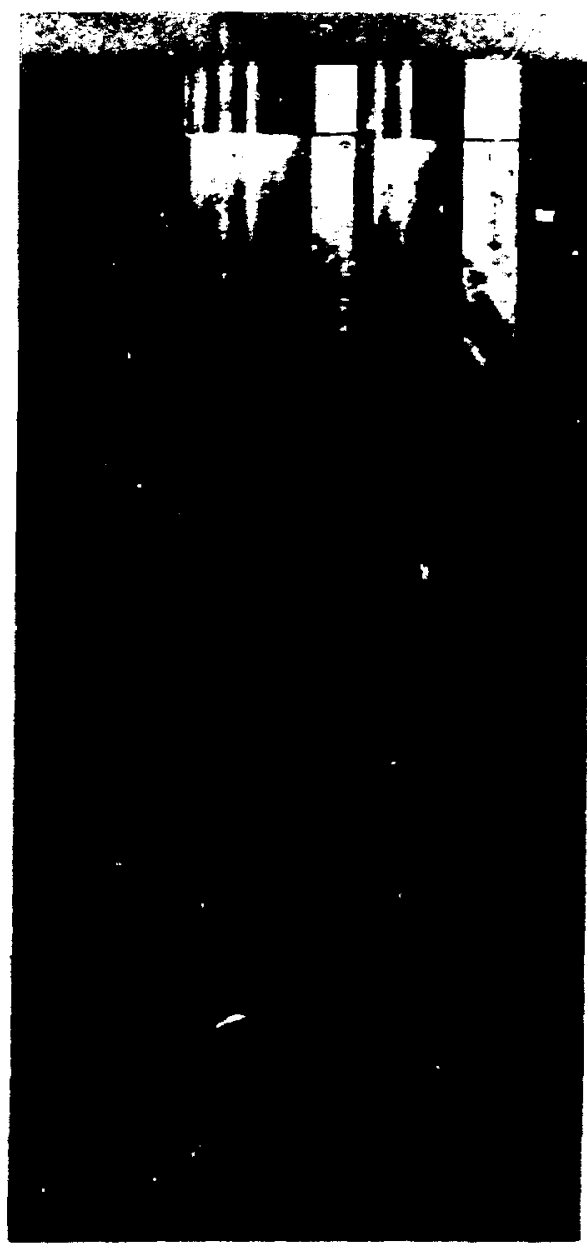

Fig. 2. Detector head with door open to accommodate side entry of samples. 


\section{DETECTOR BODY}

(cont)

Top View

Figure 3 shows a top view of the detectors in cross section. Each of the twelve ${ }^{3}$ He tubes is surrounded by a $1.5-\mathrm{cm}$-thick polyethylene $\left(\mathrm{CH}_{2}\right)$ annulus plus a $0.4-\mathrm{mm}$-thick cadmium sleeve to flatten the axial response profile of the counter and to decrease the neutron die-away time. The die-away time in the central region of the detector is $21.6 \mu \mathrm{s}$. The cadmi um sleeve stops $15 \mathrm{~cm}$ from the bottom and $17.5 \mathrm{~cm}$ from the top of the UFBC detector head (see Fin. 4) to compensate for end leakage of the neutrons and to extend the uniform counting region.

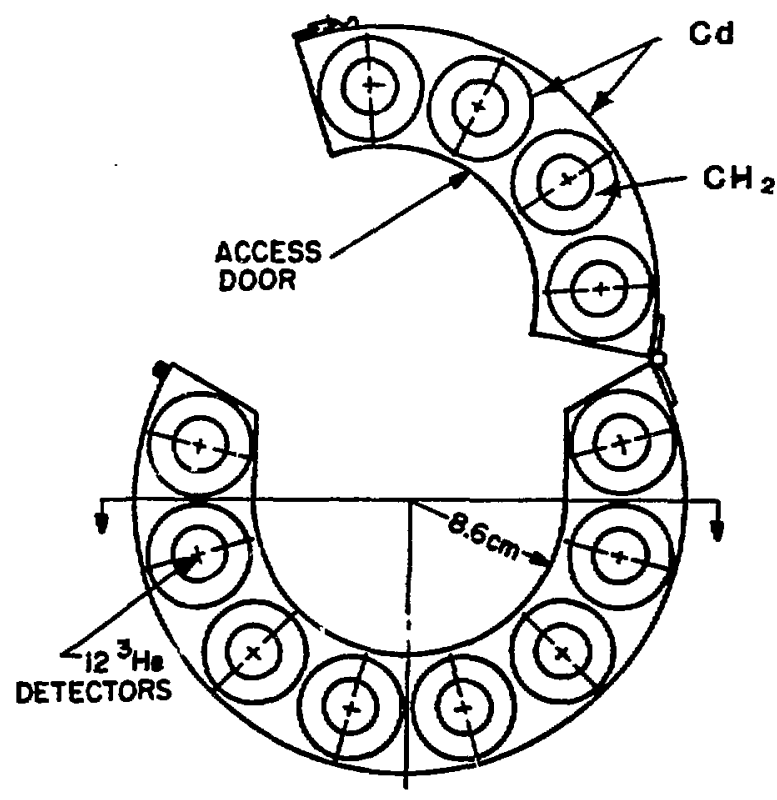

Fig. 3. Top view of detector section showing tubes and sleeves. 
DETECTOR BODY

Side View

Figure 4 is a schematic side view of the detector head in cross section. A thin (0.4- $\mathrm{mm})$ layer of cadmium lines the sample cavity to prevent thermal neutrons in the counter from returning to the sample. This cadmium is covered with an $0.8-\mathrm{mm}$ layer of aluminum to protect the cadmium. On the top and bottom of the outside of the $\mathrm{CH}_{2}$ body, a 0.4-mm-thick cadmium liner absorbs 1ow-energy, room-background neutrons.

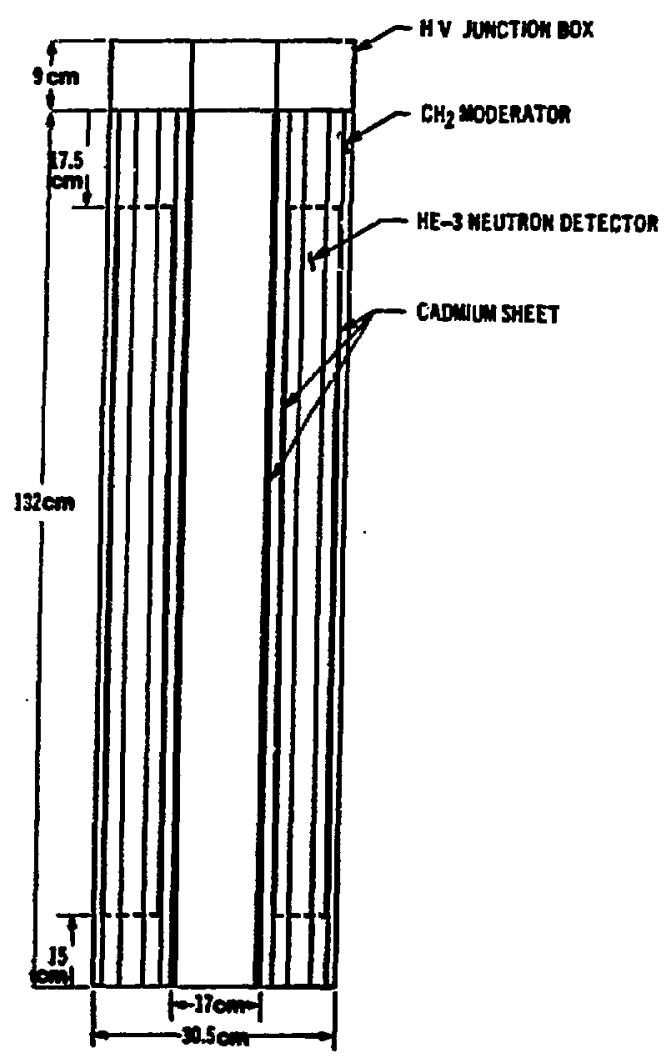

Fig. 4. Schematic side view of UFBC detector head. 
The detector stand shown in Fig. 5 is designed so that the subassembly can be lowered through the top of the counter using an overhead crane. For those facilities where the subassemblies cannot be lifted over the top of the detector, the UFBC system has a door that opens for side entry. A support platform specific to each facility may be needed.

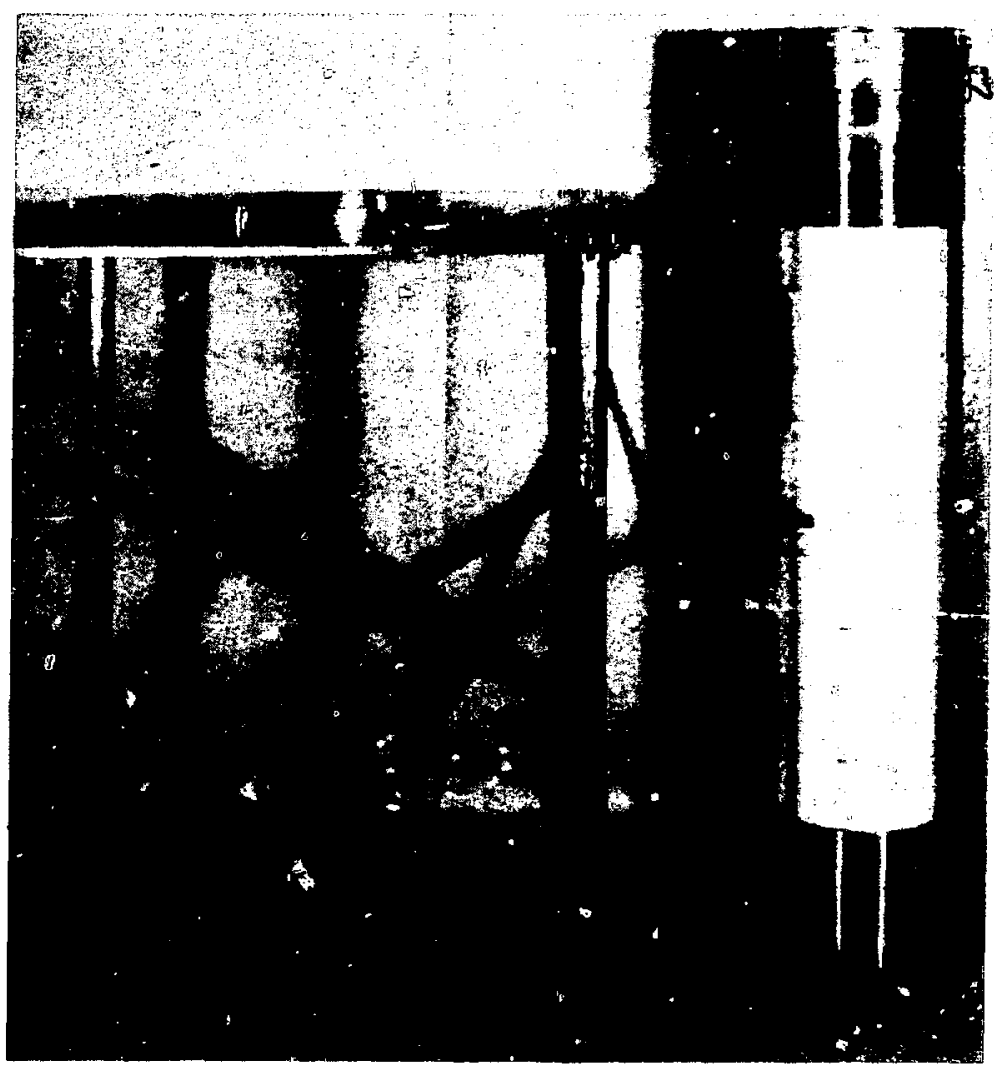

Fig. 5. Metal stand for detector head. 
CALIBRATION SOURCE
The UFBC detector head normally is equipped with a ${ }^{252} \mathrm{Cf}$ calibration normalization source. A ${ }^{252}$ Cf source should be assigned to the UFBC system, and this source should be counted at the time of calibration and at each subsequent use of the detector for normalization purposes. A source with an initial intensity of $20.02 \mu \mathrm{g}\left(5 \times 10^{4} \mu \mathrm{s}\right)$ is adequate for at least 5 years of use in the UFBC. The initial reference sources used with the UFBC unit supplied to the IAEA were $C C-15$ and $C R-5$. Sources owned by the IAEA have been crosscalibrated with the CR-5 source.

A 12-mm-diam by 381-mm-long aluminum rod is supplied with the system and used to insert the californium source into the top of the UFBC (see Fig. 0$)$. This source checks tlos system operation and can be used to normalize the calibration curve in the same manner as with the HLNCC. 


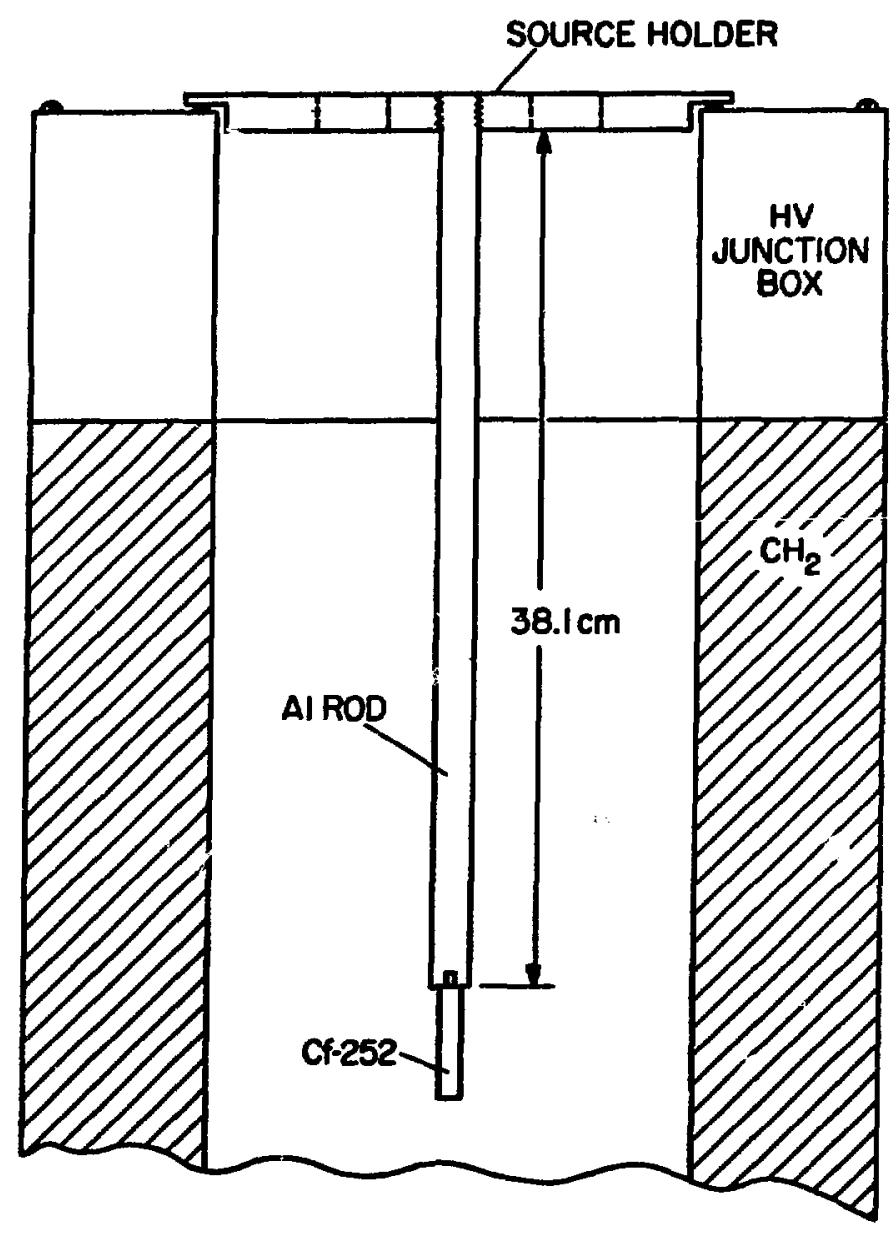

Fig. 6. $252 \mathrm{Cf}$ source and positioning rod detector head. 
DETECTOR TUBES

TABLE I

CHARACTERISTICS OF 3 He TURES

Tube model

RS-P4-0848-203

Active length

$121.9 \mathrm{~cm}$

Diameter

$2.5 \mathrm{~cm}$

Fil1 pressure

$4 \mathrm{~atm}$

Gas quench

$\mathrm{Ar}+\mathrm{CH}_{4}$

Cladding

Stainless steel

Operating high voltage

$1690 \mathrm{~V}$

ANALOG ELECTRONICS

The UFBC system uses the new fast-counting circuitry $^{3}$ based on the miniature AMPTEK hybrid chip. This chip is located near the top of the ${ }^{3}$ He tubes (see Fig. 7) and contains the preamplifier, amplifier, and discriminator circuits. Six of these amplifier units are located in the detector head (see Fig. 8). The outputs of these six amplifiers are added and sent to the input of the shift-register board. The connection is made through the "external SR input" on the back panel of the shift-register electronics.

The status of the six amplifier channels is indicated by six signal lights connected to the 


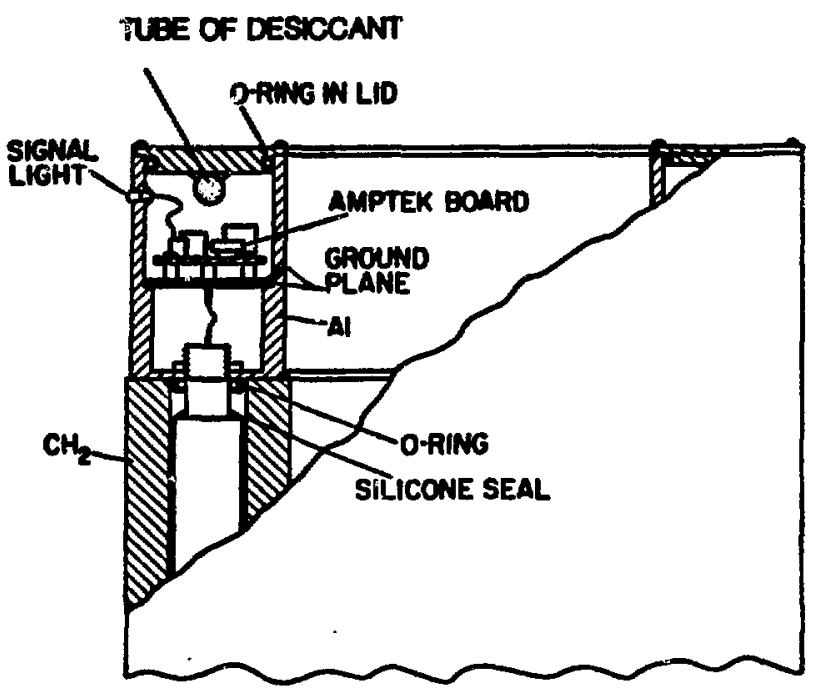

Fig. 7. Diagram of $3 \mathrm{He}$ tube and AMPTEK amplifier board.

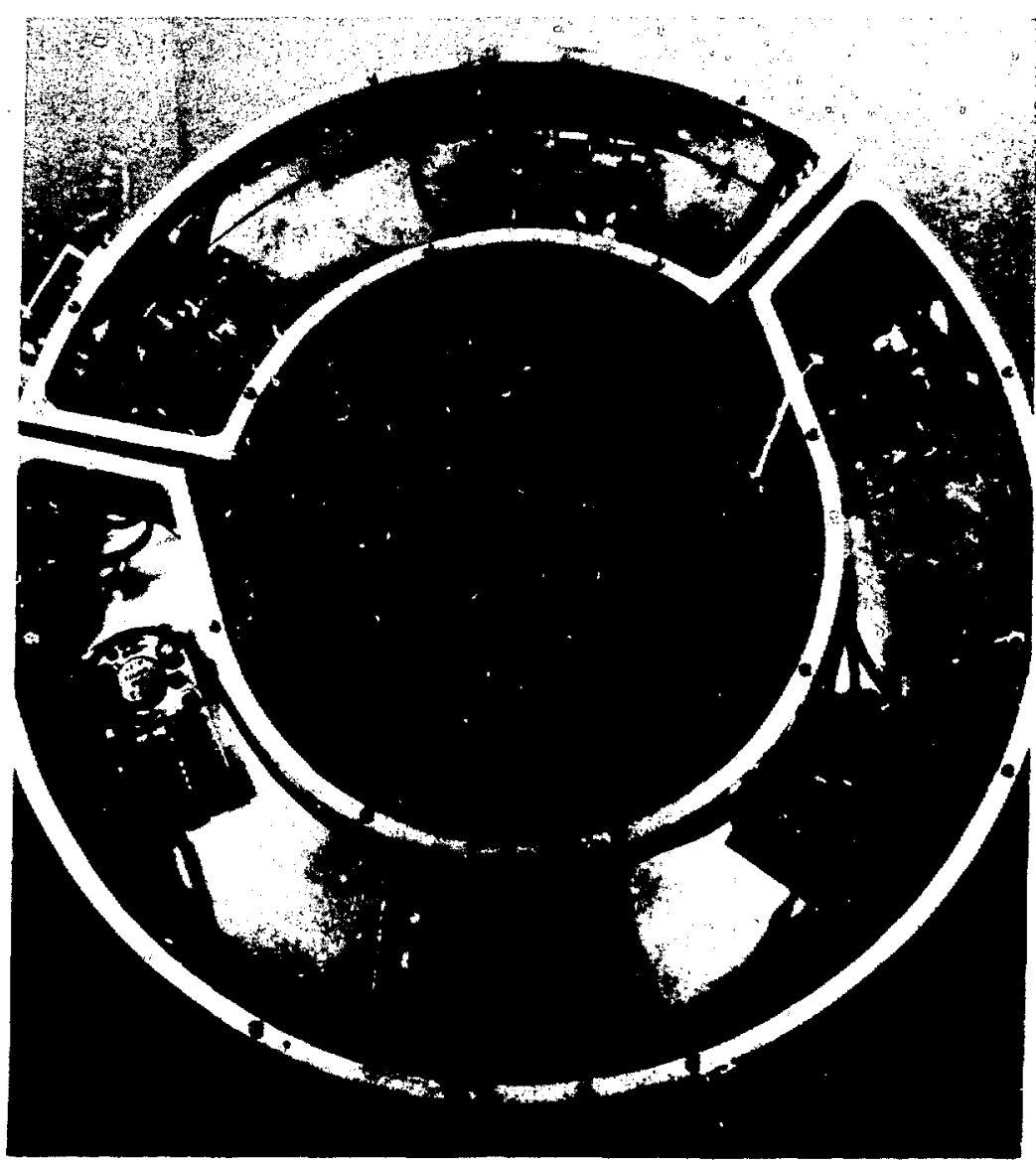

Fig. 8. AMPTEK boards in top of detector. 
NALCG ELECTRONICS

(cont)

DIGITAL ELECTPONICS

MOISTURE SEAL outputs of the six discriminators (see Figs. 7 and 8 ). These lights flash whenever the corresporiding channel processes a discriminator output pulse. The ${ }^{3}$ He tube HV section of the detector is isolated from the ASPTEK amplifier board by the ground plane shown in Fig. 7.

The shift-register electronics* for the UFBC is the same as that used for the HLNCC; however, the HEC-100 unit has been modified to provide $+5 y$ to the AMPTEK amplifier, and a derandomizing buffer has been added to the HEC-100 shift-register circuit (see Ref. 3 ).

To avoid moisture buildup in the high-voltage junction box of the detector, this space contains desiccant and the openings are sealed with 0-rings, silicone rubber, and rubber gaskets (see Fig. 7). We have applied a bead of silicone sealant around the perimeter of the ${ }^{3}$ He tubes where the HY connector screws into the aluminum tube.

*IRT Corporation, San Diego, California; HEC-100 SR electronics package. 


\section{EFFICIERCY}

DETECTOR MEUTRON

DIE-AWAY TIME
The efficiency for a ${ }^{252} \mathrm{Cf}$ neutron source in an empty counter is $7.0 \%$. The detector was designed to be undermoderated, that is, to have less polyethylene wall thickness than would be the case for maximum counting efficiency. This design accommodates the high plutonium loading in the subassemblies and keeps the counter weight low.

The proper gate setting in a neutron coincidence counter depends on the neutron die-away time $(\tau)$ in the system. For minimum error, the coincidence gate length should be set equal to $21.2 \tau$. A ${ }^{252} \mathrm{Cf}$ source was used to measure the die-away time, and the result was $21.6 \mu \mathrm{s}$. We are using a gate setting of $64 \mu \mathrm{s}$, rather than $32 \mu \mathrm{s}$, to obtain a more uniform axial efficiency profile (see Axial and Radial Response Profiles below.)

The UFBC system uses the same basic electronics and amplifiers (six channels-AMPTEK) as does the new HLNCC-II. ${ }^{4}$ Therefore, we use the same deadtime coefficient as for the HLNCC-II,

$$
\delta(T)=\left(0.62+0.20 \times 10^{-6} T\right) \mu s,
$$

where $T$ is the measured totals rate in counts/s. The corrected counting rates are

$$
T(\text { corr. })=T e^{\delta T / 4}
$$


DETECTOR DEADTIME

(cont)
AXIAL AND RADIAL

RESPONSE PROFILES and

$$
R(\text { corr. })=R e^{\delta T} \text {. }
$$

It is important to use the same deadtime coefficient for both calibration and assay, so that any errors in the correction will cancel to a first approximation.

To determine sample geometry effects, a ${ }^{252_{C f}}$ neutron point source was positioned at yarious axial locations in the sample cavity. Both totals and coincidence rates were measured at each location, and the results of the measurements using a 64 us gate are shown in Fig. 9. The uniform axial-efificiency zone of $2705 \mathrm{~cm}$ was obtained in the detector design by removing the cadmium sleeves at each end of the counter to increase the efficiency and compensate for neutron leakage. 


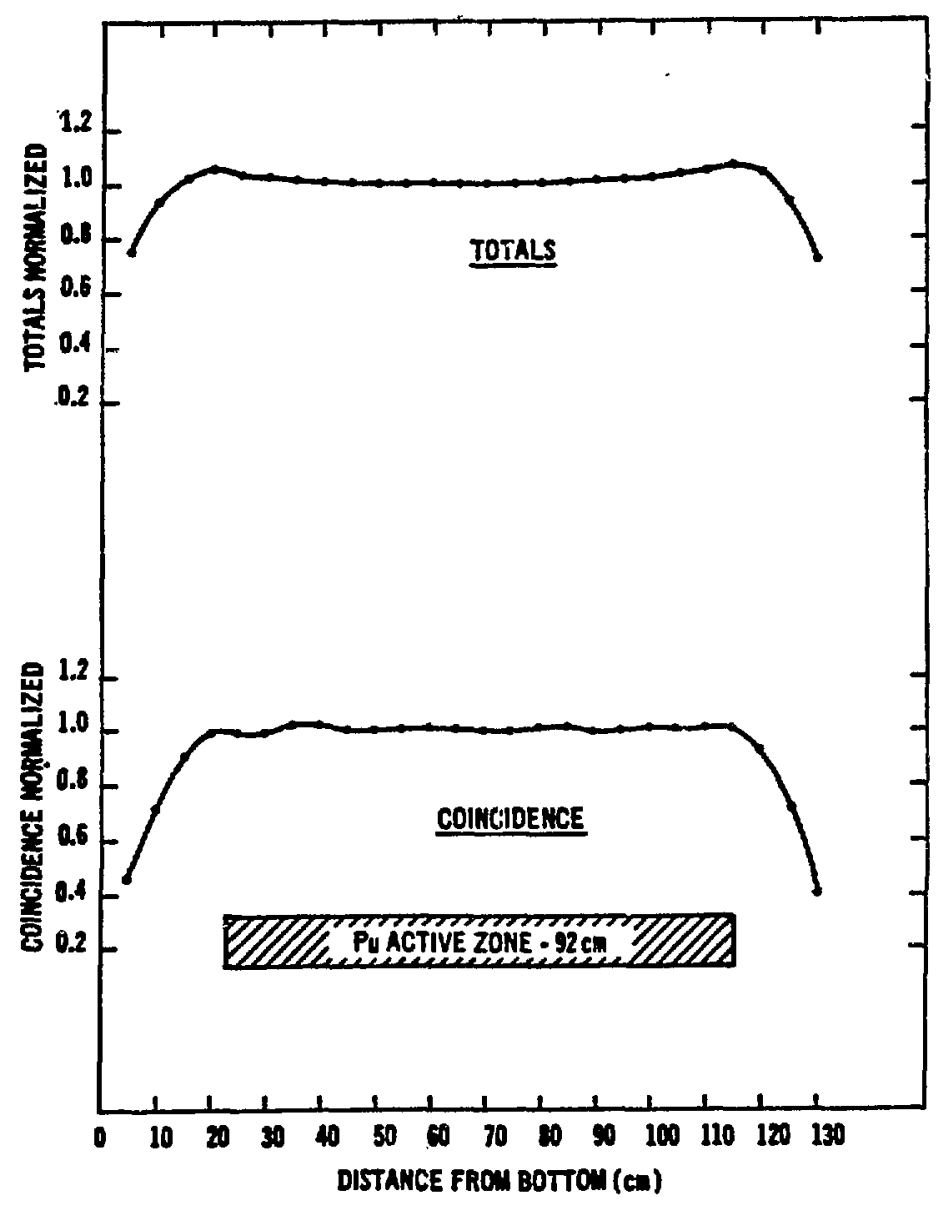

Fig. 9. Normalized totals and coincidence rates for a ${ }^{252} \mathrm{Cf}$ source as a function of axial position in the UFBC detector head. 
IMITIAL CHECK-OUT

The initial check-out and operating procedures are the same as for the HLNCC-II. Use the following procedure:

1. Connect the $\mathrm{HE} ;-100$ to the UFBC detector head using three cables (HV, $5 \mathrm{~V}$, and signal) as illustrated in Fig. 10.

2. Check the $H E C-100$ for proper 1 ine voltage $(110$ or $240 \mathrm{~V}$ ) and set controls as 1 isted below:

Discriminator leve] N/A

High voltage $=\imath 7690 \mathrm{~V}$

Gate $=64 \mu \mathrm{s}$

Time $=$ Desired run time $(200-\mathrm{s}$ recycle).

3. Turn on power and verify that the six output lights showing detected events are blinking.

4. Measure room background for $100 \mathrm{~s}$ and observe that there are no net coincidence counts above normal statistical fluctuations and that the totals rate is consistent with the amount of plutonium stored near the measurement position. 5. Place the ${ }^{252} \mathrm{Cf}$ calibration source (attached to the source holder) in the top of the UFBC detector head and take several 100-s counts.

If the counting rate (after decay corrections) is within a few per cent of the expected value from the calibration measurement, then proceed with assay and normalize the calibration to the source rate (the precision should be good to a few tenths of a per cent). 


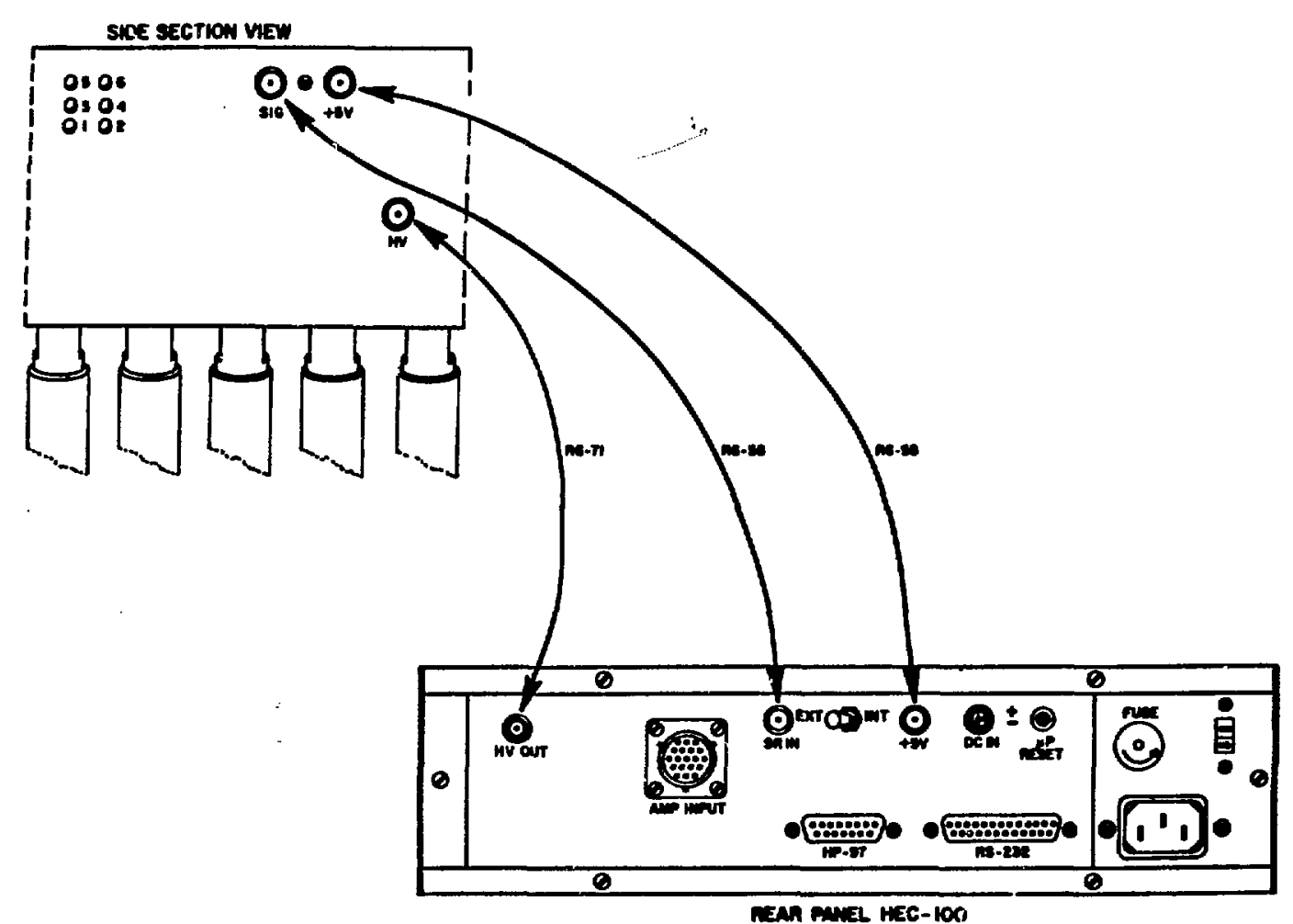

Fig. 10. Connections for the HV, $5 \mathrm{~V}$, and signal cables between the UFBC detector head and the HEC-100.

INITINL CHECK-OUT

(cont)
If the ${ }^{252} \mathrm{Cf}$ counting rate is outside the expected range, then do a thorough check on electronics as described in the Expeririental Setup section in the HLNCC manual. 1 The normalization source has to be accurately measured to obtain quantitative results based on previous calibrations.
SUBASSEMBLY ASSAY
The FBR subassemblies can be positioned in the UFBC detector head either through the top or from the side with the door open. It is necessary to obtain the location of the plutonium active zone 
SUBASSEMBLY ASSAY

(cont) in the fuel assembly from the operators' drawings or from a rough gamma-ray measurement. A health physics dosimeter with audible output can be used for this purpose. The botton of the active zone should be positioned $215 \mathrm{~cm}$ above the bottom of the UFBC detector head. This location will put the plutonium in the flat counting zone (see Fig. 9). The subassemblies should be centered in the radial direction. 


\section{CALIBRATION PROCEDURE}

To calibrate the UFBC system, fuel subassemblies are required that cover a large range of plutonium mass. Because the samples have considerable neutron multiplication, the fuel geometry, density, and isotopic content are important.

For the initial calibration work, the UFBC system was taken to the Westinghouse Hanford Company (WHC) in Richland, Washington, and measurements were made with well-characterized Fast Flux Test Facility (FFTF) fuel subassemb?ies. A series of subassemblies and fuel pins were placed in the UFBC systems, and the totals and coincidence counting rates were measured. This calibration work was similar to the prior calibration, performed in 1981, for the prototype fast breeder reactor fuel counter. 5

The preliminary calibration performed at WHC can be used to independentiy determine the $\mathrm{g} 240 \mathrm{Pu}$ effective for the plutonium in subassemblies or pins measured during inspection. A more accurate calibration can be obtained after additional subassemblies from other types of FBRs are measured covering a wider mass range.

CALIBRATION SETUP

The equipment was set up at WHC on the stand shown in Fig. 5. In addition to the UFBC detector head, we used the HEC-100 (modified for the fast AMPTEK electronics) and the HP-97 programmable calculator. 
CALIBRATION SETUP (cont)
For more complete data evaluation and graphics display, we used the new GRiD* portable computer. This computer was not interfaced to the HEC-100 during the calibration work.

For the measurements, we lowered the FFTF subassemblies through the top of the UFBC detector head so that the plutonium active zone was centered in the detector.

In this position, the bottom of the subassembly was $14 \mathrm{~cm}$ above the floor level. The start of the $91.4-\mathrm{cm}$ active zone is $120.6 \mathrm{~cm}$ above the bottom of the fuel assembly. The subassemblies were centered radially by means of the metal spacing fins that already were attached to the subassembly.

The subassemblies were measured for several cycles of $200 \mathrm{~s}$ each as time permitted. The statistical precision was between 0.4 and $0.7 \%$.

After completing the normal measurements, the cadmium liner was removed from the sample cavity of the UFBC and the measurements were repeated. This second response was larger than for the cadmium case because of the returning thermal neutrons causing fissions, and the increase is a measure of the fissile content in the fuel.

₹The GRTD Computer is manufactured by GRiD Systems Corp. 
CALIBRATION SETUP

(cont)
A smal1 ${ }^{252} \mathrm{Cf}$ neutron source (CC-15) was measured periodically during the experiment to provide future calibration nomalization. The ${ }^{252} \mathrm{Cf}$ source was attached to the end of a $38.1-\mathrm{cm}-1$ ong aluminum rod for insertion in the top of the UFBC (see Fig. 6).

POSITION SENSITIVITY TESTS To determine the sensitivity of the totals and coincidence rates to the location of the subassembly in the counter, a series of measurements were made with varying axial and radial positions.

Axial Position

One of the fuel subassemblies was measured at several axial positions to determine the sensitivity of the detector to the sample's vertical position. The results of these measurements are given in Table II. Because of the poor statistics in the coincidence rate due to the short counting times $(20 \mathrm{~s})$, only the totals rates were used to check the profile. The rate did not change significantly when the bottom of the assembly was in the range of 5 to $30 \mathrm{~cm}$ above the floor. For the FFTF fuel, the plutonium active length is $91.4 \mathrm{~cm}$.

Radial Position

A fuel subassembly was measured in several different radial positions to determine the sensitivity of the counter to positioning error.

Four times the operator removed and replaced the assembly into the counter to a constant height, 


\section{TABLE II}

AXIAL SCAN DATA FOR FFTF SUBASSEMBLY $\# 8195$

\begin{tabular}{|c|c|c|}
\hline $\begin{array}{l}\text { Distance to } \\
\text { Floora } \\
(\mathrm{cm}) \\
\end{array}$ & $\begin{array}{l}\text { Totals Rateb } \\
\text { (counts/s) } \\
\end{array}$ & $\begin{array}{l}\text { Normalized } \\
\text { Rate }\end{array}$ \\
\hline 0 & 146922 & 0.993 \\
\hline 5 & 147700 & 0.998 \\
\hline 10 & 147948 & 0,999 \\
\hline $15^{\mathrm{a}}$ & 147796 & 0.999 \\
\hline 20 & 148171 & 1.001 \\
\hline 25 & 148384 & 1.002 \\
\hline 30 & 147236 & 0.995 \\
\hline $\begin{array}{l}--- \\
35\end{array}$ & 143969 & 0.973 \\
\hline 40 & 138752 & 0.939 \\
\hline 45 & 132139 & 0.893 \\
\hline 50 & . 125093 & 0.845 \\
\hline
\end{tabular}

ale positioned the fuel assemblies $14 \mathrm{~cm}$ above the floor for the calibration measurements. bata has not been corrected for background and deadtime.

Radial Position (cont) each time achieving a normal visual centering by making a reasonable number of crane movements that might be expected in routine field use. A fifth time, the assembly was purposefully positioned so that it was touching one side of the detector. Each time, five repeated 
Radial Position

(cont) 200-s counts were obtained for the totals rate and coincidence rate.

The physical reason for the change in rate with position is that the efficiency $(\varepsilon)$ increases near the inside walls of the sample cavity. The totals counting rate $T$ varies as $\varepsilon$, and the coincidence rate $R$ varies as $\varepsilon^{2}$. Thus, if you analyze the variation in $T$ and double the variation, it will be approximately the same as for $R$ for small variations. The reason for looking at the $T$ parameter is that its statistics are very good. For example, $\sqrt{T} / T \times 100=0.0086 \%$ where $T$ (ave) $=133949$ counts $/ \mathrm{s}$ for each of the 200-s runs.

The counting error on $T$ is negligible, and almos. all of the observed variation is from positioning changes or electronic stability and room background variations. The room and electronic stability for $T$ can be estimated from the five individual counts of $200 \mathrm{~s}$ each for which there was no movement. Table III gives a summary of these data.

The average scatter about the mean $(x)$ for each fixed position was $0.024 \%$; however, the scatter about the mean for the four different positions was $0.19 \%$, almost 10 times larger with the repositioning. This difference implies that the scatter in the coincidence rate $R$ should be roughly $2 \times 0.19 \%$ or $20.4 \%$, which is within the 
TABLE III

REPOSITIONING DATA SUMYARY FOR SÜBASSEMBLY MUMBER 16471

\begin{tabular}{|c|c|c|c|c|c|c|c|c|}
\hline \multirow[b]{2}{*}{ Position } & \multicolumn{5}{|c|}{ 200-s Totals Rates } & \multirow[b]{2}{*}{$T$} & \multirow[b]{2}{*}{$\underline{s}$} & \multirow[b]{2}{*}{ sq } \\
\hline & 1 & 2 & 3 & 4 & 5 & & & \\
\hline 1 & 133909 & 133905 & 133904 & 133926 & 133861 & 133901 & 24 & 0.018 \\
\hline 2 & 134337 & 134342 & 134273 & 134313 & 134304 & 134314 & 28 & 0.021 \\
\hline 3 & 133740 & 133699 & 133651 & 133691 & 133732 & 133703 & 35 & 0.027 \\
\hline \multirow[t]{4}{*}{4} & 133910 & 133908 & 133895 & 133876 & 133875 & 133881 & 39 & 0.029 \\
\hline & & & & & $x=$ & 133949 & & \\
\hline & & & & & $s=$ & 258 & & \\
\hline & & & & & $5 \%=$ & $0.192 \%$ & & \\
\hline
\end{tabular}

\section{Radial Position} (cont) uncertainty of the direct analysis of the $R$ values.

In a separate measurement, subassembly number 8195 was counted in the center $(1000 \mathrm{~s})$ and then touching the wall $(1000 \mathrm{~s})$. The counting rates are listed in Tabie IV.

In summary, the maximum positioning error in the coincidence rate $R$ is $\sim 0.8 \%$ (based on the totals data) and, with reasonable care in centering the assembly, this error should be less than $0.4 \%$.

A11 of the normal data runs for the FFTF fuel had the "positioning collar" in place. The collar consists of the metal fins that are placed around the FFTF subassemblies to center them in the floor 
TABLE IV

RADIAL GEOMETRIC VARIATIONS FOR SUBASSEMBLY 8195

\begin{tabular}{|c|c|c|c|c|}
\hline Position & $T$ & $\mathbf{R}$ & (T) Wall/Cente & $r$ Ratio \\
\hline 16 & $151682 \pm 12$ & $9193 \pm 53$ & -- & $\ldots$ \\
\hline gainst Wall & $152266 \pm 12$ & $9316 \pm 54$ & $1.0039 \pm 0.0001$ & $1.013 \pm 0.008$ \\
\hline
\end{tabular}

NOTE: The totals rate increased by $0.39 \%$; thus, the expected increase in $R$ is $20.8 \%$, which is consistent with the observed increase of $1.3 \pm 0.8 \%$.

Radial Position (cont) storage pipes. Therefore, positioning variability is not a problem at WHC, and the positioning exercise was directed towards facilities other than the FFTF reactor. Precautions need to be taken for subassemblies where the diameter is small compared with the detector size.

STANDARDS SPECIFICATIONS

The standards used in the calibration were both subassemblies and fuel pin tubes. The hexagonal subassemblies contained 217 pins $(0.584 \mathrm{~cm}$ in diameter), and the distance across flats was $12 \mathrm{~cm}$. Figure 11 is an isometric drawing of the subassembly components.

Table $V$ gives the plutonium content and isotopics of the four subassemblies and three pin tubes used for the calibration. All of the isotopic 


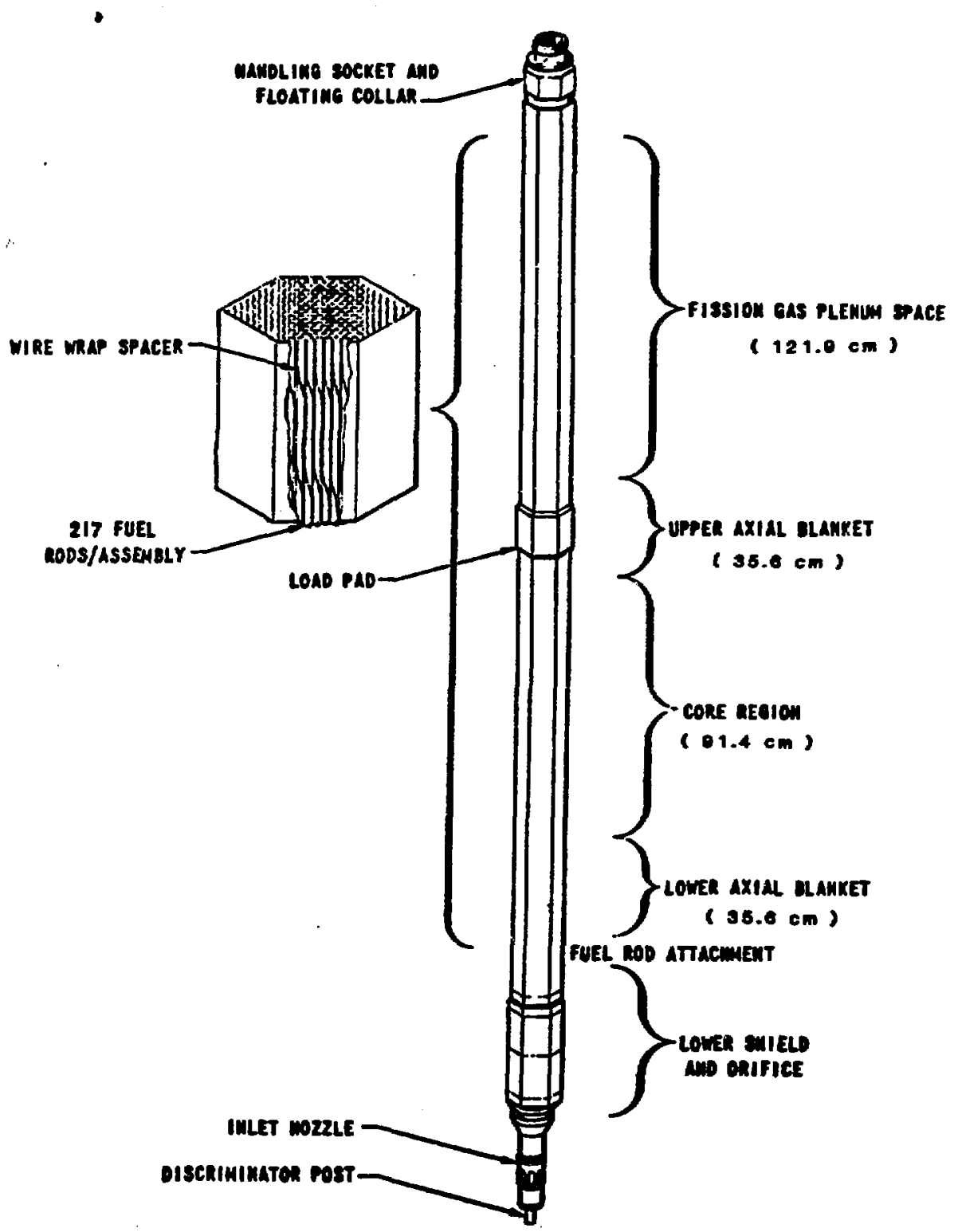

Fig. 11. Standard FFTF fuel subassembly. 
TABLE V

STANDARDS DATA

\begin{tabular}{|c|c|c|c|c|c|c|c|c|}
\hline \multirow[b]{3}{*}{ Standard } & \multicolumn{2}{|c|}{ Pu Content } & \multicolumn{6}{|c|}{ Isotopic Compositiona } \\
\hline & \multirow{2}{*}{$\begin{array}{c}240 \mathrm{Pu} \\
\text { Eff }\end{array}$} & \multirow{2}{*}{$\begin{array}{c}P u \\
\text { Total } \\
\end{array}$} & \multicolumn{5}{|c|}{$\mathbf{P u}$} & \multirow{2}{*}{$\begin{array}{l}\mathrm{An} \\
\underline{241} \\
\end{array}$} \\
\hline & & & 238 & 239 & 240 & 241 & 242 & \\
\hline \multicolumn{9}{|l|}{ Pin Tubes } \\
\hline 4 Pins & 18.42 & 153.67 & 0.060 & 87.03 & 11.55 & 1.13 & 0.150 & 0.365 \\
\hline 82 Pins & 377.24 & 3144.20 & 0.056 & 87.15 & 11.52 & 1.086 & 0.192 & 0.352 \\
\hline 120 Pins & 542.0 & 4595.65 & 0.048 & 87.34 & 11.47 & 1.00 & 0.197 & 0.324 \\
\hline \multicolumn{9}{|c|}{ Subassemblies } \\
\hline 16483 & 908.23 & 7395.86 & $0: 058$ & 36.63 & 11.85 & 1.244 & 0.211 & 0.609 \\
\hline 16471 & 1011.64 & 8385.74 & 0.048 & 87.08 & 11.65 & 1.012 & 0.211 & 0.599 \\
\hline 8195 & 1102.68 & 9108.35 & 0.058 & 86.75 & 18.70 & 1.29 & 0.191 & 0.597 \\
\hline 8255 & 1205.60 & 9733.68 & 0.058 & 86.78 & 11.78 & 1.15 & 0.231 & 0.343 \\
\hline
\end{tabular}

aThe isotopic data in weight per cent of the plutonium have been corrected to July $27,1983$.

STANDARDS SPECIFICATIONS (cont) data have been updated to the time of the measurements (July 27, 1983).

The pin tubes contained a maximum of 120 pins, each pin inside a thin (0.8-mm-thick) plastic sleeve for physical protection. The sleeves tend to increase neutron moderation and multiplication. However, the pin tubes do not have the fast neutron reflector at the end of the plutonium active zone. The lack of scattering material tends to decrease the coincidence response compared with that of the subassembly. 


\section{CALIBRATION RESULTS}

Calibration measurements were performed using the four FFTF subassemblies and the three pin storage tubes. Totals and coincidence counts were made both with and without the cadmium liner. The active zone of the plutonium was centered in the detector for all of the samples.

Measurement results are listed in Table VI for measurements with the cadmium liner in the normal position and in Table VII for measurements with the cadmium liner removed. Both measurements were taken io see if the difference $R_{\text {No }} C d$ - $R_{C d} \equiv \Delta R$ could be used to predict the fissile content.

TABLE YI

UFBC COLNTER CALIBRATION DATA (Cd MODE)

\begin{tabular}{|c|c|c|c|c|c|}
\hline Sanple & $\begin{array}{c}\text { Run Timeb } \\
\text { (s) }\end{array}$ & $\begin{array}{l}\text { Cotnc. } \\
\text { Deadtime }\end{array}$ & $\begin{array}{l}\text { T Cd } \\
\left(s^{-1}\right)\end{array}$ & $\begin{array}{l}K C_{d}^{d} \\
\left(s^{-1}\right)\end{array}$ & $\begin{array}{l}\text { Scatter } b \\
70(8)\end{array}$ \\
\hline \multicolumn{6}{|l|}{ Pin Tubes } \\
\hline 4 Pins & $20 \times 500$ & 1.001 & 2125 & $79.64 \pm 0.28$ & 1.57 \\
\hline 82 Pins & $6 \times 200$ & 1.030 & 47720 & $2461.6 \pm 19.0$ & 1.83 \\
\hline 120 pins & $5 \times 200$ & 3.045 & 70957 & $4069.6 \pm 37.2$ & 1.95 \\
\hline
\end{tabular}

\section{Subassemblies}

$\begin{array}{rrrrrr}16483 & 6 \times 200 & 1.079 & 122118 & 7025.7 \pm 37.4 & 1.12 \\ 16471 & 5 \times 200 & 1.089 & 136053 & 8069.4 \pm 47.6 & 1.01 \\ 8195 & 10=100 & 1.099 & 151542 & 9192.6 \pm 52.9 & 1.53 \\ 8255 & 5 \times 200 & 1.106 & 161128 & 10348.0 \pm 68.9 & 1.34\end{array}$

Hormalization Source

$\begin{array}{lllllll}252 & \text { Cf(CC-i5) } & 12 \times 5000 & 1.001 & 1105 & 96.3 \pm 0.3 & 0.77\end{array}$ (27 July 1983)

\footnotetext{
A11 counting rates have been corrected for room background.

bihe run time designation of $20 \times 500$ corresponds to 20 runs of $500 \mathrm{~s}$ exch. and the per cent scatter is one standard deviation measured from the 20 rins. CThe coincidence deadtiwe correction corresponds to $\mathrm{e}^{\sigma T}$, where \& $=$ $\left(0.608+0.236 \times 10^{-6} \mathrm{~T}\right) \mu \mathrm{s}$, and the predelay was $3.0 \mathrm{\mu s}$.

The error given for $R$ corresponds to $10=\sqrt{R+(R+A)}$.
} 
TABLE VIJ

UFBC COUNTER CALIBRATION DATA (NO-C $C$ MOOE)

\begin{tabular}{|c|c|c|c|c|c|c|}
\hline \multirow{2}{*}{$\begin{array}{c}\text { Sample } \\
\text { Pin Tubes }\end{array}$} & \multirow[t]{2}{*}{$\begin{array}{c}\text { Run Time } \\
\text { (s) }\end{array}$} & \multirow[t]{2}{*}{$\begin{array}{l}\text { Coinc. } \\
\text { Deadtine }\end{array}$} & \multirow[t]{2}{*}{$\begin{array}{l}f c d \\
\left(s^{-7}\right)\end{array}$} & \multicolumn{2}{|c|}{$\begin{array}{l}\text { R No } c d \\
\left(s^{-1}\right)\end{array}$} & \multirow[t]{2}{*}{$\begin{array}{l}\text { Scatter } \\
10(x)\end{array}$} \\
\hline & & & & & & \\
\hline 4 Pins & $11 \times 500$ & 1.002 & 2204 & \multicolumn{2}{|c|}{$86.18 \pm 0.58$} & 3.31 \\
\hline 82 Pins & $5 \times 200$ & 1.033 & 51314 & 3051 & \pm 19 & 1.41 \\
\hline 120 pins & $5 \times 200$ & 1.050 & 77673 & 5254 & \pm 29 & 1.21 \\
\hline \multicolumn{7}{|c|}{ Subassembities } \\
\hline 76483 & $5 \times 200$ & 1.086 & 131154 & 8734 & \pm 48 & 1.28 \\
\hline 16471 & $5 \times 200$ & 1.096 & 145981 & 10055 & \pm 52 & 1.22 \\
\hline 8195 & $5 \times 200$ & 1.108 & 163182 & 11636 & \pm 61 & 0.63 \\
\hline 8255 & $5 \times 200$ & 1.116 & 173472 & 12851 & \pm 63 & 1.12 \\
\hline
\end{tabular}

Normalizätion Source

${ }^{252_{\text {Cf }(C C-15)}} 2 \times 100 \quad 1.001 \quad 1105 \quad 96.3 \pm 1.0 \quad--$

(27 July 1983)

CALIBRATION RESULTS (cont)
The room background totals rate was subtracted from the data giyen in Tables VI and VII. This background ranged from 150 counts/s when the fue 1 was in the normal storage position to 1400 counts/s when a subassembly was in the welding machine adjacent to the UFBC system. In all cases, the coincidence background was zero. When repeat measurements were made of the background with and without the welding machine in operation, no differences were observed.

Figure 12 shows the coincidence response versus the ${ }^{240} \mathrm{Pu}$-effective for measurements both with and without the cadmium liner. The separation in the two curves is caused by fission in the fissile material induced by the reflected thermal neutrons. The magnitude of the separation is proportional to the fissile loading and the total neutron emission rate from the sample. 


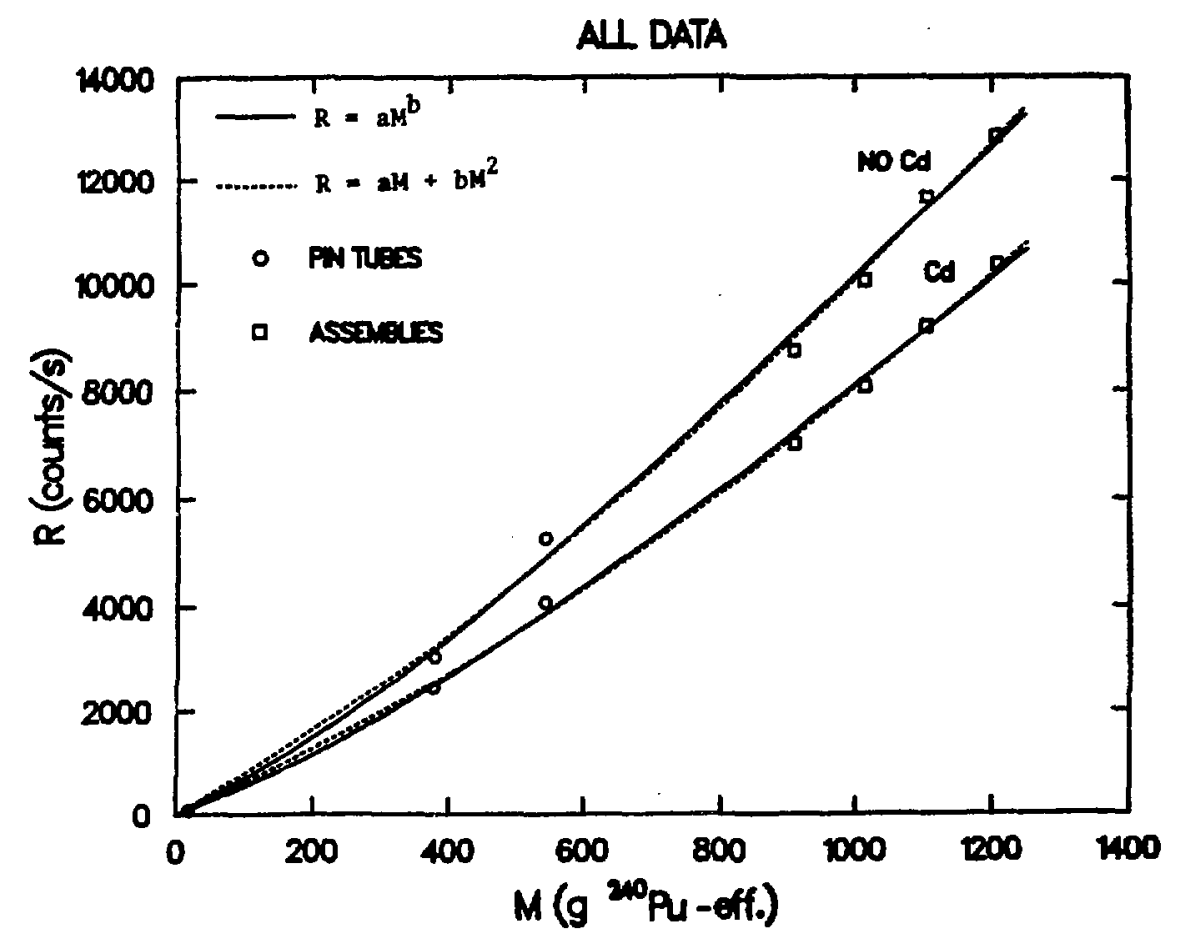

Fig. 12. Measured coincidence rate as a function of 240 Pu-effective content.

CALIBRATION RESULTS (cont)
The fully loaded pin tube sample data falls above the calibration curve because of the neutron moderation in the $\mathrm{CH}_{2}$ sleeves. The low energy neutrons cause an increase in the neutron multiplication.

The upward curvature of the calibration curves shown in Fig. 12 is caused by neutron multiplication in the samples. Because the multiplication has a strong effect on the measurement FBR subassemblies, a multiplication correction should be applied to the data. This corrrection requires

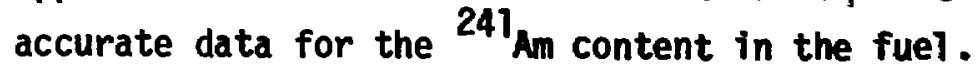




\section{CALIBRATION RESULTS} (cont)

GRAPHICAL CORRECTION

The two following sections will deal with making corrections for the neutron multiplication.

A graphical correction ${ }^{6}$ for multiplication can be obtained from the graph (Fig. 13) of $R / M$ versus $(1+\alpha) R / T$, where

$$
\begin{aligned}
& R=\text { coincidence rate, } \\
& M=g{ }^{240} \text { Pu-effective, } \\
& \alpha=(\alpha, n) / \text { spontaneous fission ratio, and } \\
& T=\text { totals counting rate }
\end{aligned}
$$

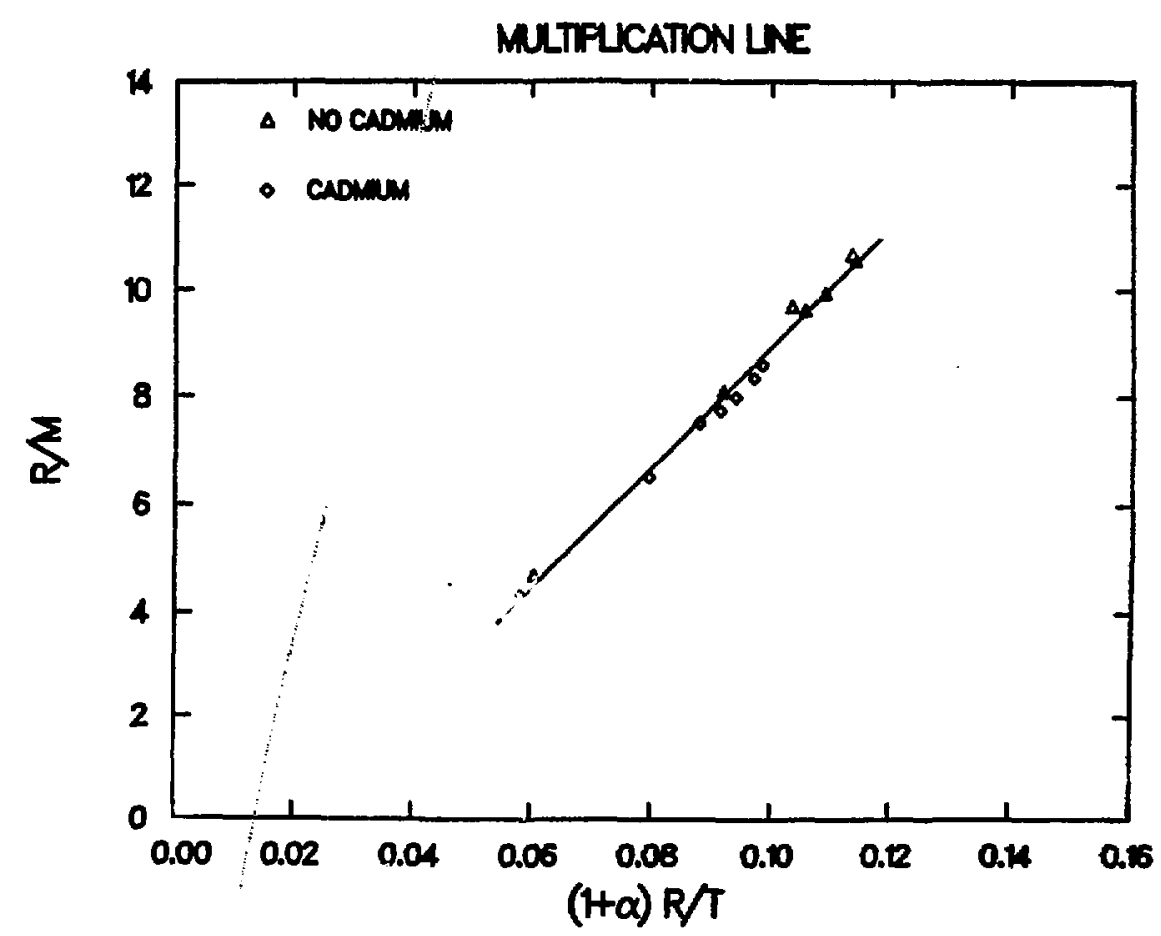

Fig. 13. Correction line for neutron multiplication. 
GRAPHICAL CORRECTION (cont)
THEORETICAL CORRECTION
A straight line connects the data for both detector configurations, demonstrating that the samples all have the stated isotopic mixture and $(\alpha, n)$ fraction. If there were no multiplication, the lines would degenerate to a point and all of the samples would coincide. Because $R$ and $R / T$ are measured, the line in Fig. 13 can be used to find $\mathrm{g} 240 \mathrm{Pu}$-effective independent of multiplication. This procedure will work for any sample of known isotopic mixture and containing no impurities with high $\alpha, n$ yields.

A theoretical correction ${ }^{7}$ can be made for multiplication based on the technique developed for the HLNCC. We used the following parameters (see Ref. 6) for the correction:

$$
\begin{aligned}
& \alpha_{0}=\simeq(0.58) \text { (from } p \text { lutonium isotopics), } \\
& \rho_{0}=R_{0} / T_{0} \text { (for nonmultiplying sample), } \\
& \alpha=\simeq(0.58) \text { (from isotopics), } \\
& \rho=R / T \text { (measured), } \\
& r=\frac{\rho(1+\alpha)}{\rho_{0}\left(1+\alpha_{0}\right)},
\end{aligned}
$$

where $\rho_{0}\left(1+\alpha_{0}\right)$ is from the zero mass intercept in Fig. 14,

$$
\begin{aligned}
& A=3(1+\alpha), \\
& B=-(3.022+4.192 \alpha+0.8689 r), \\
& C=1.192(\alpha)+0.8909, \\
& M=\frac{-B+\sqrt{B^{2}-4 A C}}{2 A},
\end{aligned}
$$




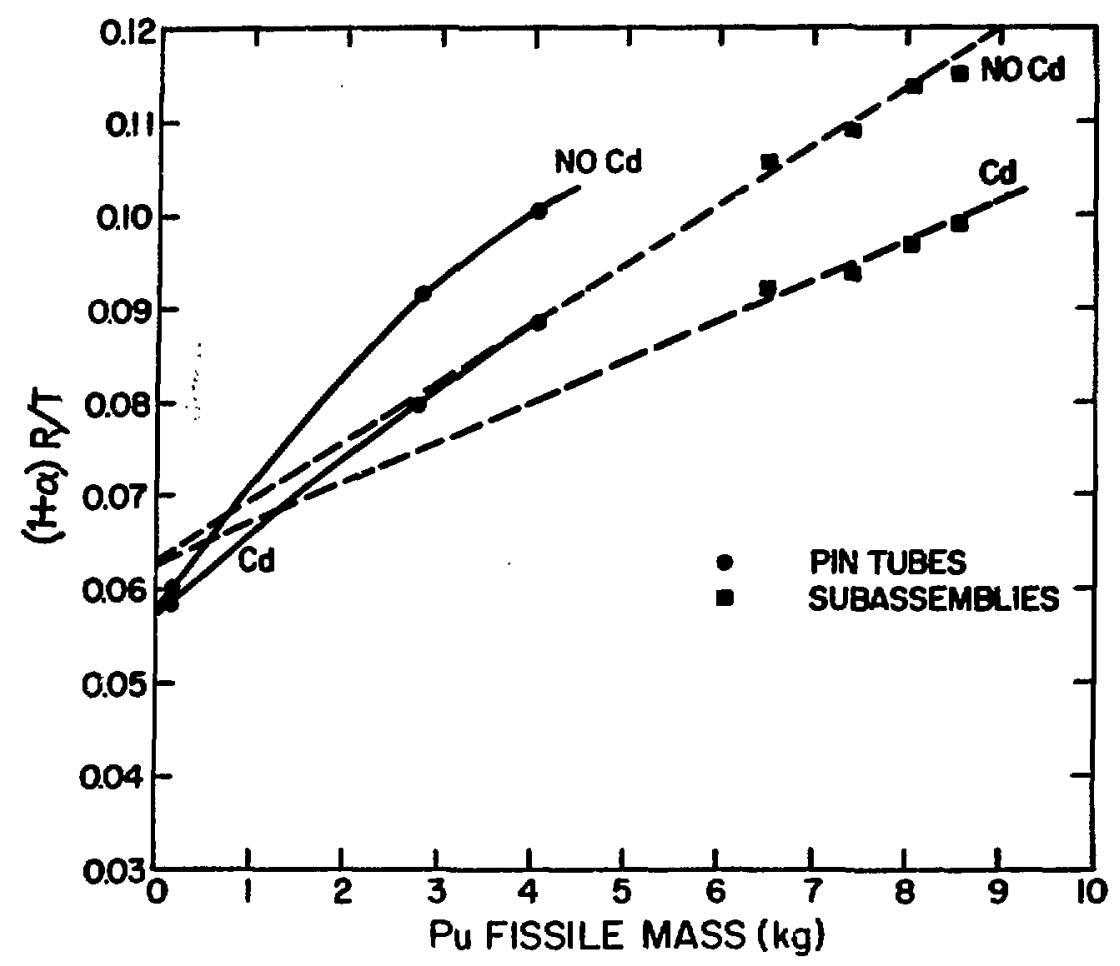

Fig. 14. Zero mass intercept for obtaining the value of $\rho_{0}\left(1+\alpha_{0}\right)$.

THEORETICAL CORRECTION (cont)

$$
\begin{aligned}
& C F=M r \text {, and } \\
& R_{C}=R_{m} / C F .
\end{aligned}
$$

The correction factor CF was calculated for each of the samples, and the corrected coincidence rates $R_{c}$ are plotted in Fig. 15 for the cadmium case and Fig. 16 for the no-cadmium case. In addition, the $\mathrm{R} / \mathrm{g}$.values before and after correction are plotted as a function of mass $\left(g{ }^{240} \mathrm{Pu}\right.$ effective) in Fig. 17 for the cadmi un case and Fig. 18 for the no-cadmium case. 


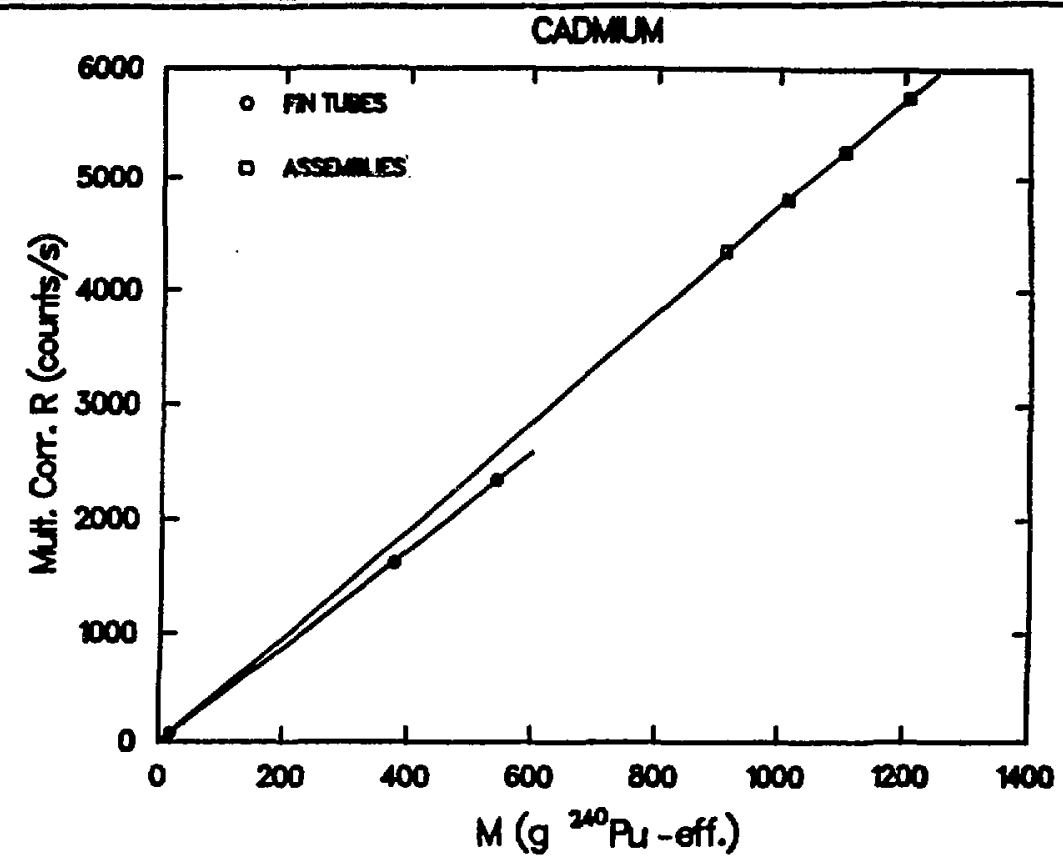

Fig. 15. Corrected coincidence rates $\left(R_{C}\right)$ for the cadmium mode.

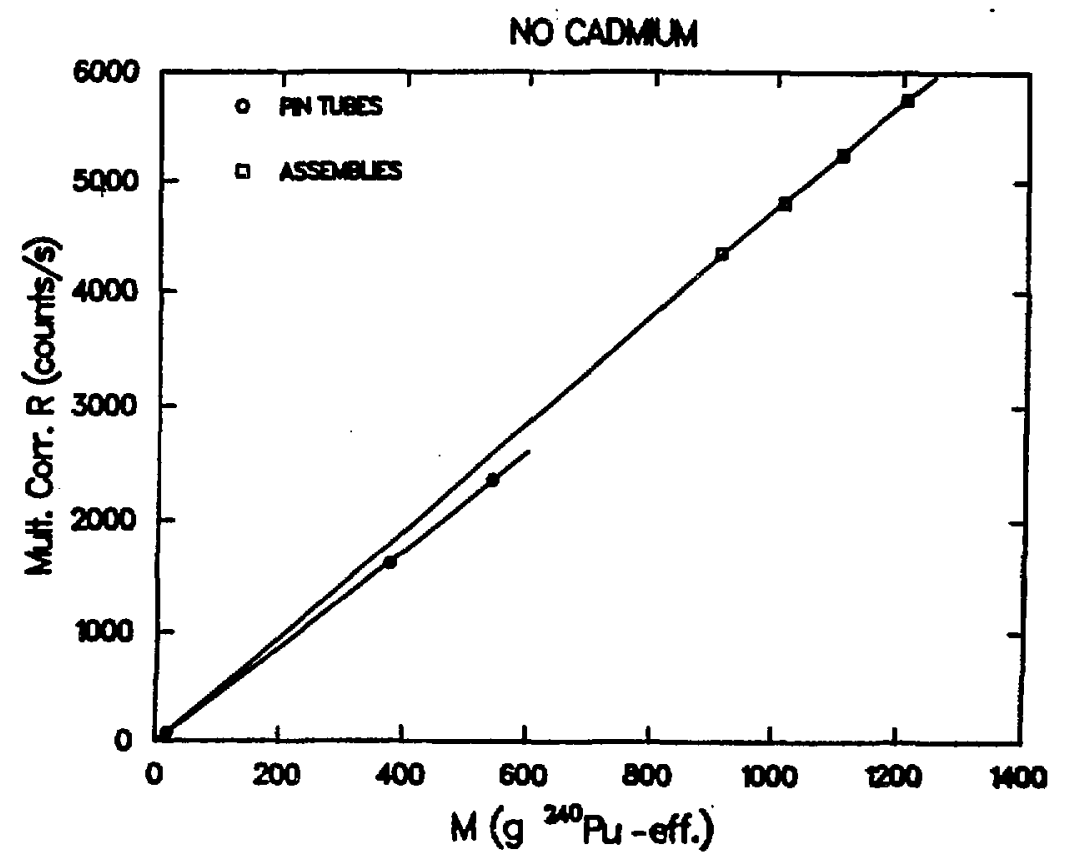

Fig. 16. Corrected coincidence rates $\left(R_{C}\right)$ for the no-cadni um mode. 


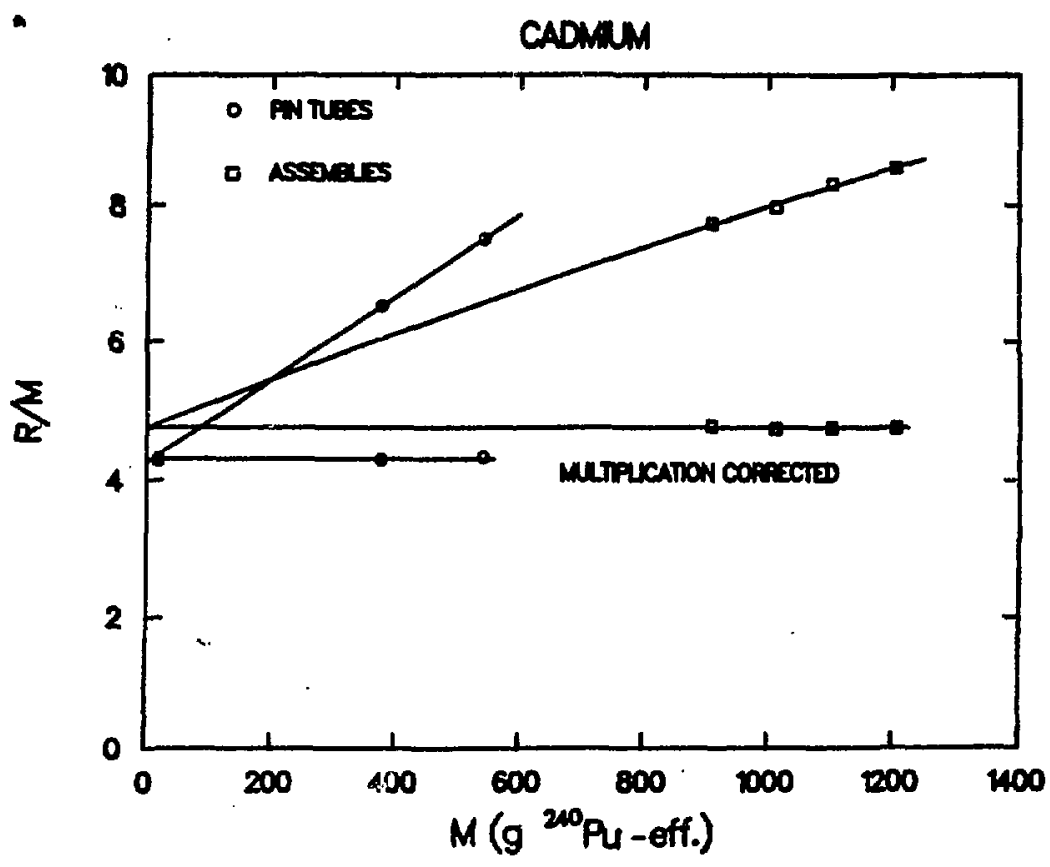

Fig. 17. Multiplication corrected coincidence response per unit mass (cadmium mode) vs mass (g $240 \mathrm{pu}$-effective).

Fig. 18. Multiplicaicion corrected coincidence response per unit mass (nocadmi um mode) vs mass ( $\mathrm{g}$ 240pu-effective).

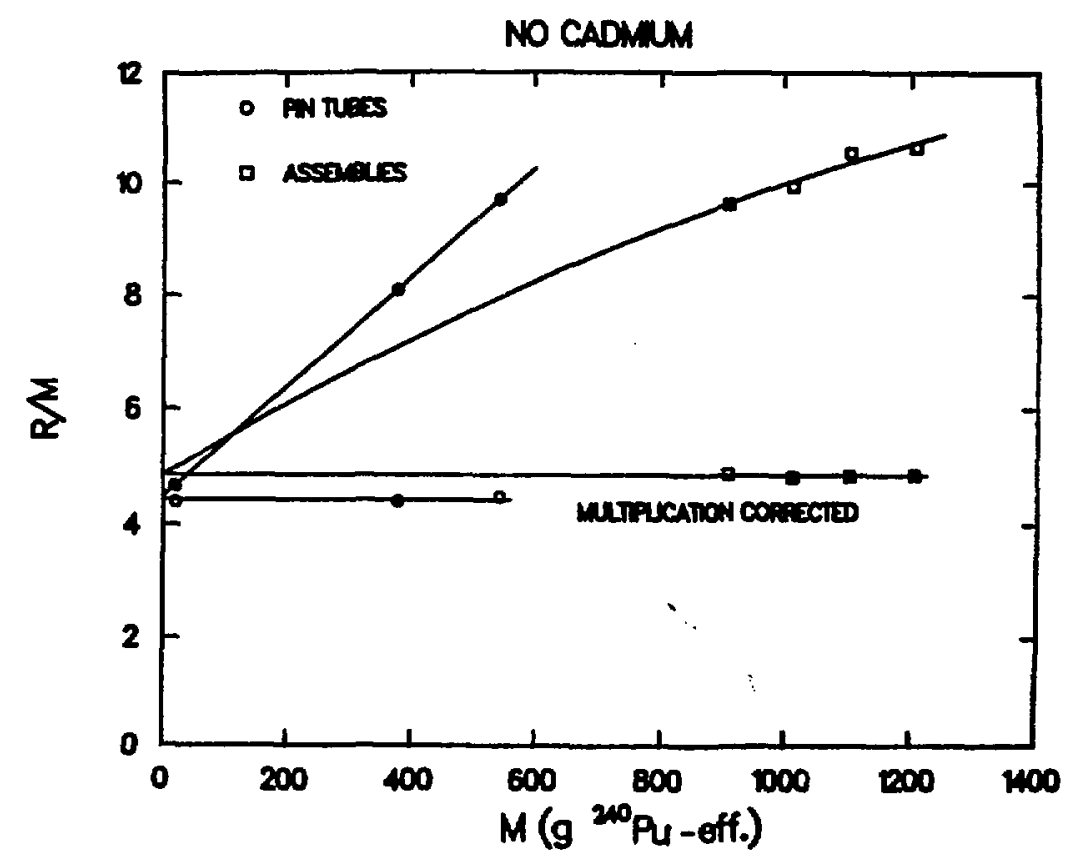


THEORETICAL CORRECTION (cont)
CALIBRATION FUNCTIONS
The nonlinear behavior of the coincidence response is caused by multiplication, and the correction technique ${ }^{6}$ currently in use by the IAEA can be used to make the response 1 inear (see Figs. 15-18). It is important to use the same $\rho_{0}$ $\left(1+\alpha_{0}\right)$ value for both the calibration and the assay.

Table VIII 1ists the calculated multiplication parameters for the standards. When you are using these parameters for future calibrations, it will be necessary to adjust $\rho_{0}$ for any changes in the efficiency because of electronic settings. The use of ${ }^{252}$ Cf to check the efficiency is described in the section on Californium Normalization.

Two different types of calibration functions (the power function and the quadratic polynomial function) have been used previously for FBR subassemblies. In addition, a linear function is used for the response after multiplication corrections.

There is no clear answer as to whether the power function or the quadratic polynomial gives a better fit. Near the origin (that is, for low mass samples), the quadratic polynomial function has more flexibility than the power function because it can vary with both mass $m$ and $m^{2}$. For the pin tube data, the quadratic polynomial fits the data better than the power function. On the other hand, for highly multiplying samples (very high mass range), the power function has more 


\section{TABLE VIII}

CALIBRATION PARAMETERS AFTER MULTIPLICATION CORRECTIONS

$\frac{\text { Parameters }}{C d \text { case }}$
$\frac{C}{R}$
$\rho$
$\rho_{0}\left(1+\alpha_{0}\right)^{a}$
$r$
$M$
$C F$
$R_{C}$
$R_{C} / g b$
$N_{0} C d$ Case
$R$
$\rho$
$\rho_{0}\left(1+\alpha_{0}\right)^{a}$
$r$
$M$
$C F$
$R_{C}$
$R_{C} / g^{b}$

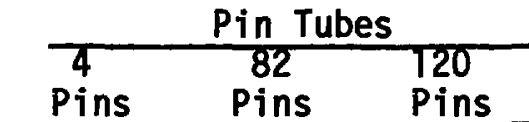

\begin{tabular}{|c|c|c|c|}
\hline \multicolumn{4}{|c|}{ Subassemblies } \\
\hline 16483 & 16471 & 8795 & 8255 \\
\hline $\begin{array}{l}0.585 \\
7026 \\
0.5753 \\
0.0630 \\
1.4474 \\
1.1166 \\
1.6162 \\
4347 \\
4.786\end{array}$ & $\begin{array}{l}0.582 \\
8069 \\
0.05931 \\
0.0630 \\
1.4893 \\
1.1273 \\
1.6789 \\
4806 \\
4.751\end{array}$ & $\begin{array}{l}0.597 \\
9192 \\
0.06066 \\
0.0630 \\
1.5377 \\
1.1381 \\
1.7500 \\
5252 \\
4.763\end{array}$ & $\begin{array}{l}0.530 \\
10348 \\
0.0642 ? \\
0.0630 \\
1.5596 \\
1.1489 \\
1.7919 \\
5775 \\
4.789\end{array}$ \\
\hline
\end{tabular}

$\begin{array}{cll}0.551 & 0.542 & 0.530 \\ 79.64 & 2462 & 4070 \\ 0.03748 & 0.05159 & 0.05736 \\ 0.0578 & 0.0578 & 0.0578 \\ 1.0057 & 1.3763 & 1.5184 \\ 1.0016 & 1.1012 & 1.1385 \\ 1.0074 & 1.5156 & 1.7286 \\ 79.059 & 1624 & 2354 \\ 4.292 & 4.306 & 4.344\end{array}$

$\begin{array}{cll}86.18 & 3051 & 5254 \\ 0.03910 & 0.05946 & 0.06764 \\ 0.0578 & 0.0578 & 0.0578 \\ 1.049 & 1.586 & 1.7905 \\ 1.014 & 1.155 & 1.2064 \\ 1.064 & 1.832 & 2.1600 \\ 81.03 & 1666 & 2432 \\ 4.399 & 4.416 & 4.488\end{array}$

8734
0.06659
0.0630
1.6753
1.1726
1.9644
4446
4.895

10055
0.06888
0.0630
1.7297
1.1859
2.0513
4902
4.846

11636

12851

0.071310 .07408

$0.0630 \quad 0.0630$

$1.8077 \quad 1.7990$

$1.2029 \quad 1.2085$

$2.1744 \quad 2.1742$

5351
4.853

5911

4.902

${ }^{a}$ The value of $\rho_{0}\left(1+\alpha_{0}\right)$ was obtained from Fig. 14 at zero mass.

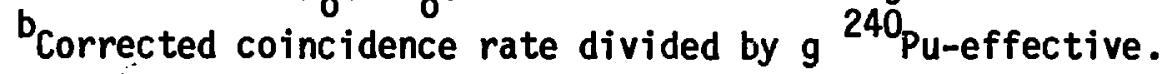

CALIBRATION FUMCTIONS (cont) flexibility in that it varies as $m^{b}$, where $b$ is fit to the data, whereas the quadratic is restricted to the form $m^{2}$ (the $m$ term becomes negligible). For the subassembly data, both functions gave equivalent fits to the data.

In the following sections, we will fit the data to both the power function and the quadratic function, so the user can have a choice. As 
CALIBRATION FUACTIONS (cont) additional calibration data from other FBR reactors become available, it might be apparent which functional form is better. For the present calibration work, we have four different calibration categories:

1. Pin tubes (cadmium mode)

2. Pin tubes (no-cadmium mode)

3. Subassemblies (cadnium mode)

4. Subassemblies (no-cadmitum mode)

Figure 12 shows all four categories and leastsquares fits of data to quadratic functions and power functions. We will now fit the categories separately to get more accurate fits. The two sample categories are basically different in that for the pins the plutonium was varied by removing pins from the pin tubes, whereas for the subassemblies the plutonium was varied by changing the enrichment while the number of pins and moX remained constant. These two sample categories should not be combined in a single calibration curve.

Because the detector is undermoderated, the scattering of neutrons in the fuel and cladding of the 217 pins increases the neutron counting efficiency in the UFBC system. Separate measurements using a ${ }^{252} \mathrm{Cf}$ source and steel pins were used to estimate the magnitude of the efficiency increase to be $210 \%$. 
FITTIMG RESULTS

Curve fitting using the Deming's Procedure 8,9 was made to the data in Tables VI and VII for both the power function and the guadratic function. The results are given in. Table IX.

TABLE IX

FITTING PARAMETERS FOR CALIBRATION FUNCTIONS

\begin{tabular}{|c|c|c|c|c|c|c|}
\hline \multirow[b]{2}{*}{ Sample } & \multicolumn{2}{|c|}{$R=a m^{b}$} & \multicolumn{4}{|c|}{$R=a m+b m^{2}$} \\
\hline & a & b & $\underline{s}^{a}$ & a & b & $\underline{s}^{a}$ \\
\hline Pin Tubes (cd) & $\begin{array}{r}0.9585 \\
\pm 0.6973\end{array}$ & $\begin{array}{r}1.3259 \\
\pm 0.1178\end{array}$ & 62 & $\begin{array}{c}4.270 \\
\pm 0.0204\end{array}$ & $\begin{array}{r}0.005976 \\
\pm 0.000043\end{array}$ & 3 \\
\hline Pin Tubes (no $C d$ ) & $\begin{array}{r}0.4347 \\
\pm 0.4345\end{array}$ & $\begin{array}{c}1.4931 \\
\pm 0.00949\end{array}$ & 42 & $\begin{array}{r}4.4171 \\
\pm 0.0038\end{array}$ & $\begin{array}{r}0.009735 \\
\pm 0.000077\end{array}$ & 1 \\
\hline Subassemblies (Cd) & $\begin{array}{c}0.5757 \\
\pm 0.118\end{array}$ & $\begin{array}{r}1.3809 \\
\pm 0.0295\end{array}$ & 4 & $\begin{aligned} & 5.0447 \\
& \pm 0.234\end{aligned}$ & $\begin{array}{r}0.002945 \\
\pm 0.000219\end{array}$ & 4 \\
\hline Subassemblies (no $\mathrm{Cd}$ ) & $\begin{array}{l}0.67636 \\
\pm 0.2410\end{array}$ & $\begin{array}{r}1.3897 \\
\pm 0.0750\end{array}$ & 1 & $\begin{array}{r}6.2050 \\
\pm 0.6772\end{array}$ & $\begin{array}{c}0.003766 \\
\pm 0.0006377\end{array}$ & 1.5 \\
\hline All samples (Cd) & $\begin{array}{r}1.9256 \\
\pm 0.5053\end{array}$ & $\begin{array}{r}1.2083 \\
\pm 0.0379\end{array}$ & 4.9 & $\begin{array}{r}5.9942 \\
\pm 0.3194\end{array}$ & $\begin{array}{r}0.0020812 \\
\pm 0.000315\end{array}$ & 4.1 \\
\hline All samples (no $C d$ ) & $\begin{array}{r}2.6655 \\
\pm 0.9332\end{array}$ & $\begin{array}{r}1.1938 \\
\pm 0.0506\end{array}$ & 9.1 & $\begin{array}{r}7.6924 \\
\pm 0.5870\end{array}$ & $\begin{array}{r}0.002420 \\
\pm 0.000578\end{array}$ & 8.7 \\
\hline
\end{tabular}

aThe parameter s corresponds to a relative "goodness of fit" parameter for a particular data set where the smaller the value the better the fit. The comparison is meaningful only for fits of different functions to the same data set. 
FITTING RESULTS

(cont)
Figure 19 shows the fitting results for the pin tube samples, and Fig. 20 corresponds to the subassemblies. The upper curves correspond to the no-cadmium mode, and the bottom curves are for the normal cadmium-1 ined detector.

The quadratic function fits the data better for the pin tubes in the low-mass region, and both functions are equivalent for the subassemblies.

FN TUEES

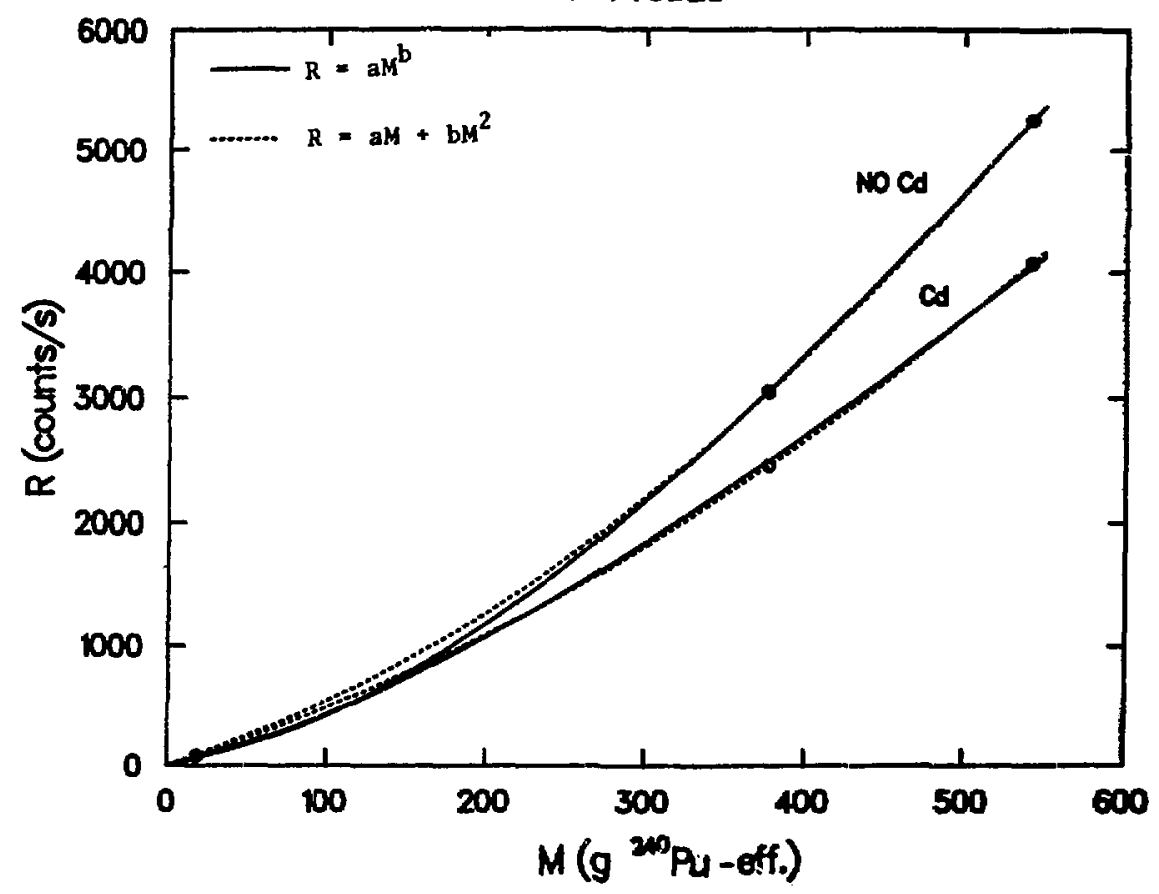

Fig. 19. Coincidence response calibration functions for pin storage tubes. 


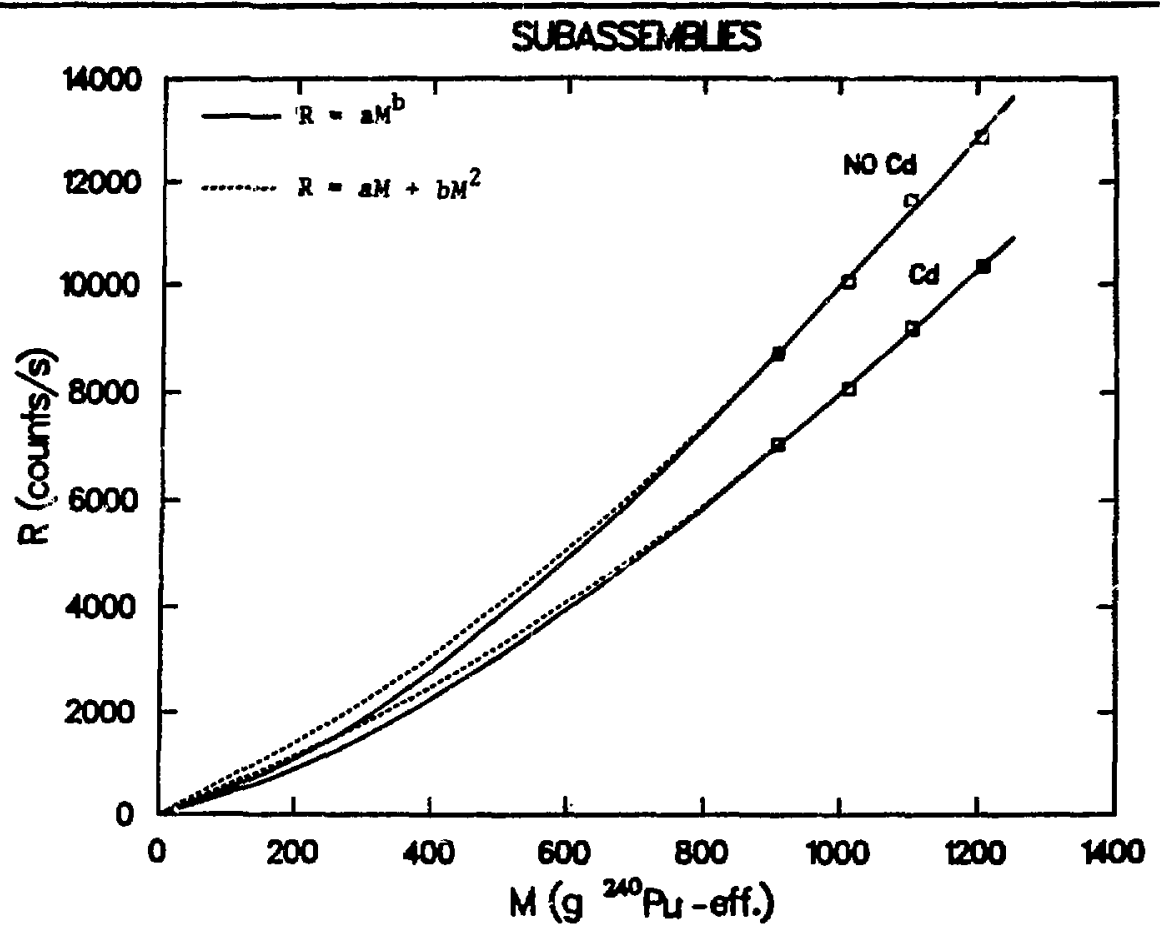

Fig. 20. Coincidence response calibration functions for subassemblies.

CALIFORNIUN MORMLLIZATION

The calibration of the UFBC counter can be carried forward in time by using the ${ }^{252} \mathrm{Cf}$ neutron source normalization method. To do this, the net totals rate $T_{0}$ and the coincidence rate $R_{0}$ are measured at the time of calibration with subassembly standards. At any future time, the ${ }^{252} \mathrm{Cf}$ source is remeasured and the values of $R$ and $T$ are compared (after decay correction) with the original rates. The normalizations are made as follows:

$$
R_{c}=R_{m} k_{1} \text {, }
$$

where 


\section{CALIFORNIUN NOREMLIZATION} (cont)
$R_{C}=$ corrected coincidence rate

$R_{m}=$ measured coincidence rate

$$
k_{1}=\left(\frac{R_{0}}{R}\right)_{C f} ;
$$

similarly,

$$
T_{c}=T_{m} k_{2},
$$

where

$$
k_{2}=\left(\frac{T_{0} \text { net }}{T \text { net }}\right)_{C f}
$$

Note that $k_{1}$ and $k_{2}$ are not equal and that, in general,

$$
k_{1} \simeq\left(k_{2}\right)^{2}
$$

It is not necessary to use the same ${ }^{252} \mathrm{Cf}$ source for normalization as was used for calibration, as long as the second source is cross-calibrated wit the original source. To avoid an error buildup this procedure, the statistical precisions for th ${ }^{252} \mathrm{Cf}$ measurements should be good $(20.2 \%)$.

For the specific case of the UFBC system calibration at Westinghouse, Richland, we measured CC-15 with

$$
\begin{aligned}
& R_{0}=96.3 \pm 0.3 \text { counts } / \mathrm{s} \\
& T_{0}=1105 \pm 15 \text { counts } / \mathrm{s}
\end{aligned}
$$


CALIFORNIUM MOFAALIZATION (cont) on July 27,1983 . These rates were obtained with the $H V=1690 \mathrm{~V}$, a $64 \mu \mathrm{s}$ gate, and a $3.0 \mu \mathrm{s}$ predelay. The calibration data listed in Tables VIII and IX correspond to the above settings.

This calibration information can be related to the IAEA sources listed in Table $X$ by using the ratios to $C R-5$ where $C R-5 / C C-15$ was measured to be $5.511 \pm 0.03$.

\section{TABLE $X$}

CALIFORNIUM-252 SOURCE STANDARDS INTERCOMPARISON SUMMARY

\begin{tabular}{lllll}
$\begin{array}{c}\text { Source } \\
\text { Number }\end{array}$ & $\begin{array}{c}\text { Absolute Yield } \\
11 / 17 / 83 \\
(\mathrm{n} / \mathrm{s})\end{array}$ & $\begin{array}{c}\text { Relative } \\
\text { Yield }\end{array}$ & $\begin{array}{c}\sigma_{\mathrm{R}} \\
(\%)\end{array}$ & $\begin{array}{c}(11 / 17 / 83) \\
(\mu \mathrm{g})\end{array}$ \\
\cline { 2 - 3 } & $\begin{array}{llll}\left(\% .77 \times 10^{4}\right. \\
\text { IPL F274 }\end{array}$ & 0.7278 & 0.2 & 0.0247 \\
IPL F275 & $5.33 \times 10^{4}$ & 0.6716 & 0.2 & 0.0228 \\
IPL F276 & $5.30 \times 10^{4}$ & 0.6676 & 0.2 & 0.0227 \\
IPL F277 & $5.74 \times 10^{4}$ & 0.7231 & 0.2 & 0.0245 \\
IPL F278 & $5.63 \times 10^{4}$ & 0.7097 & 0.2 & 0.0241 \\
IPL F279 & $5.20 \times 10^{4}$ & 0.6553 & 0.2 & 0.0222 \\
CR-5 & $7.93 \times 10^{4}$ & 1.000 & 0.2 & 0.0339 \\
CC-15 & $1.44 \times 10^{4}$ & 0.1815 & 0.2 & 0.0062
\end{tabular}

The absolute yields were determined by intercomparison with CR- 6 that was cal ibrated by National Bureau of Standards with an accuracy of $\pm 1.2 \%$ on October 16, 1979. 
CALIFORNIUM MORAALIZATION (cont)

Example Normalization Calculation

Using IAEA source IPL F276 on June 1, 1984,

F276/CC-15 $=3.678$ (from Tab7e $X$ ),

$R_{0}(F 276)=3.678(96.3)$ on July 27,1983 , and

$T_{0}(F 276)=3.678(1105)$.

Updating to June 1, 1984 ,

$$
\begin{aligned}
& \Delta \text { time }=0.844 y, \lambda=0.2623 \mathrm{y}^{-1}, \text { and } \\
& \mathrm{e}^{-\lambda \Delta \tau}=0.8014 \text { (californium source decay). }
\end{aligned}
$$

Calibration rates corrected to June 1, 1984 . are

$$
\begin{aligned}
& R_{0}(F 276)=3.678(96.3)(0.8014)=283.8 \\
& \text { counts/s, } \\
& T_{0}(F 276)=3.678(1105)(0.8014)=3257 \\
& \text { counts/s, } \\
& k_{1}=\left(\frac{R_{0}}{R}\right)_{C f}=\left(\frac{283.8}{R}\right)_{C f} \text {, and } \\
& k_{2}=\left(\frac{T_{0}}{T}\right)_{C f}=\left(\frac{3257}{T}\right)_{C f} \text {, }
\end{aligned}
$$

where $R$ and $T$ are the measured rates for ${ }^{252_{C}} \mathrm{f}$ on June 1, 1984. 
GENERAL

DETECTOR BODY

The UFBC system has no moving parts and requires little periodic mechanical maintenance. Maintenance and repair of the shift register electronics package are the same as for the HLNCC. ${ }^{1}$

The desiccant in the junction boxes of the detector body should be changed approximately once a year if the instrument is in a humid environment. To change desiccant, use the following procedure:

1. Shut off the high voltage. Remove high-voltage cable from the tube junction box, and ground the high-voltage input.

2. Remove the screws holding the lid in place. Remove the lid from the junction box. Take care not to damage the rubber 0 -ring.

3. Remove the desiccant holder from the undersurface of the lid (see Fig. 7) and discard the old desiccant.

4. Replace the desiccant and reassemble the holder. (Note that the old desiccant can be rejuvenated by placing it in an oven overnight at $2150^{\circ} \mathrm{C}$ or until it regains its blue indicating color.)

5. Date the junction box for future reference.

AMPTEK AMPLIFIER

TEST PROCEDURES
If the measurements described in the Initial Check-out section indicate that one or more of the amplifier channels are out of specification, then additional iests are necessary. 
ANPTEK APLIFIER

TEST PROCEDURES

(cont)
The six amplifier signal lights on the detector head allow the user to observe the discriminator signal from each of the $s^{*} x$ channels at the output of the discriminator circuits.

If only one or two of the channels are out, the instrument can still be used by normalizing the coincidence response to the ${ }^{252} \mathrm{Cf}$ calibration source.

Field repairs of the AMPTEK amplifier boards can be made by plugging in a spare board in place of the bad board. 


\section{ACKNOWLEDGMENTS}

The mechanical design and fabrication of the detector head was provided by Ray Holbrooks. Ed Adams assisted in the measurements at Los A1amos to determine the detector characteristics. We thank Phil Rinard for assistance in the calibration curve fitting and data analyses. We thank W. DeMershman for arranging for the measurements at WHC and A. Dupries and L. Southam of WHC for handling the reactor fuel subassemblies.

\section{REFERENCES}

1. M. S. Krick and H. O. Menlove, "The High-Level Neutron Coincidence Counter (HLNCC): Users' Manual," Los Alamos Scientific Laboratory report LA-7779-M (ISPO-53) (June 1979).

2. J. E. Swansen, P. R. Collinsworth, and M. S. Krick, "Shift-Register Coincidence Electronics System for Thermal Neutron Counters," Nucl. Instrum. Methods 176 (1980).

3. J. E. Swansen, "Deadtime Reduction in Thermal Neutron Coincidence Counter," Los Alamos National Laboratory report LA-9936-MS (March 1984).

4. H, O. Menlove and J. E. Swansen, "High Performance Neutron Autocorrelation Counters," Q-1-84-724 (to be published as a Los Alamos National Laboratory report).

5. G. W. Eccleston, J. E. Foley, M. Krick, H. O. Menlove, P. Goris, and A. Rama1ho, "Coincidence Measurements of FFTF Breeder Fuel Subassemblies," Los Alamos National Laboratory report LA-9902-MS (ISPO-199) (Apri1 1984).

6. M. S. Krick, "Neutron Multiplication Corrections for Passive Thermal Neutron Well Counters," Los Alamos Scientific Laboratory report LA-8460-MS (ISP0-89) (July 1980). 
7. N. Ensslin, J. Stewart, and J. Sapir, "Self-Multiplication Correction Factors for Neutron Coincidence Counting," Nucl. Mater. Manage. 8, 60 (1979).

8. W. E. Deming, Statistical Adjustment of Data (John Wiley \& Sons, Inc., New York, 1948).

9. J. P. Shipley and D. B. Smith, Comps., "Safeguards and Security Status Report, February -July 1982," Los Alamos National Laboratory report LA-9595-PR (February 1983), Pp. 22-23. 


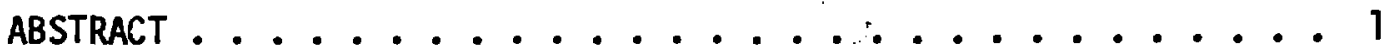

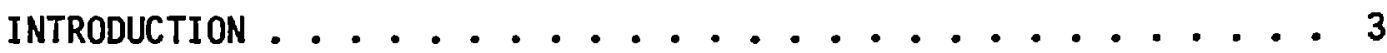

MECHANICAL COMPONENTS ................. 4 Detector Body ................ . . 4

Top View .................. 5

Side View .................. . . 6

Detector Stand .................. 7

Calibration Source .............. 8

ELECTRICAL COMPONENTS ................ 10

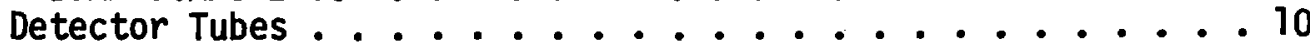

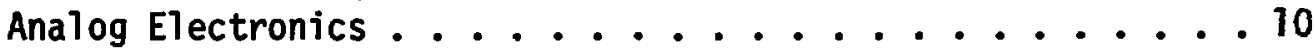

Digital Electronics ................... 12

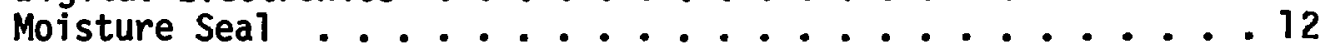

OPERATING CHARACTERISTICS .............. 13

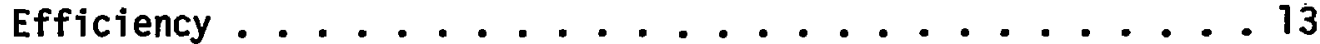

Detector Neutron Die-Away Time ............ . 13

Detector Deadtime ............... 13

Axial and Radial Response Profiles ........... 14

OPERATING PROCEDURES ................... 16

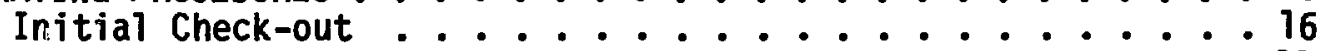

Subassembly Assay ...................... 17

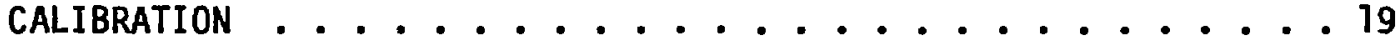

Cal ibration Procedure ............... 19

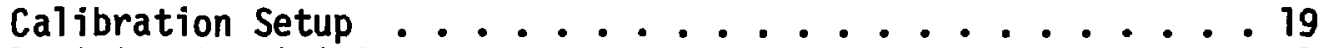

Position Sensitivity Tests . . . . . . . . . . . 21

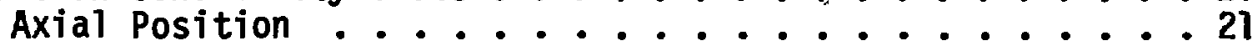

Radial Position ................. 21

Etandards Specifications ............. 25

Calibration Results .................... 28

Graphical Correction . . . . . . . . . . . . . 31

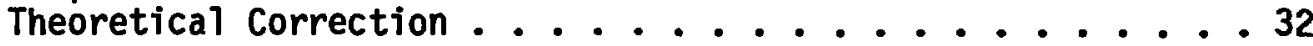

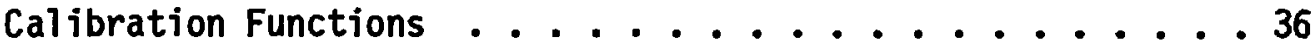

Fitting Results ................ 39

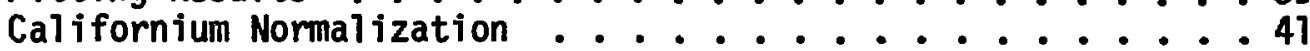

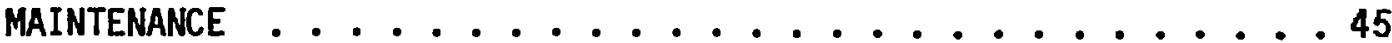

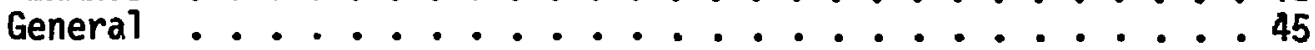

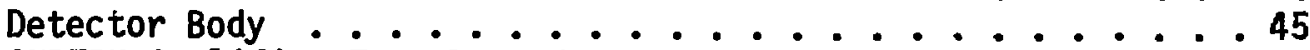

AMPTEK Amplifier Test Procedures .......... 45

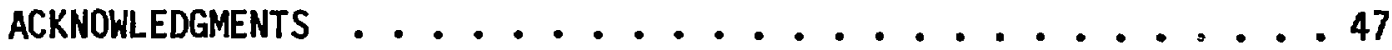

REFERENCES ...................... 4? 